\title{
PETROGLIFOS, GEOGLIFOS, RUTAS Y OTRAS MARCAS EN- TRE MAMINNA, QUIPISCA E IQUIUCA (REGIÓN DE TARAPACÁ, CHILE). USOS Y DESUSOS A TRAVÉS DEL TIEMPO
} Petroglyphs, Geoglyphs, Routes and Other Marks Between Mamiña, Quipisca and Iquiuca (Tarapacá Region, Chile). Uses and Disuses Through the Time

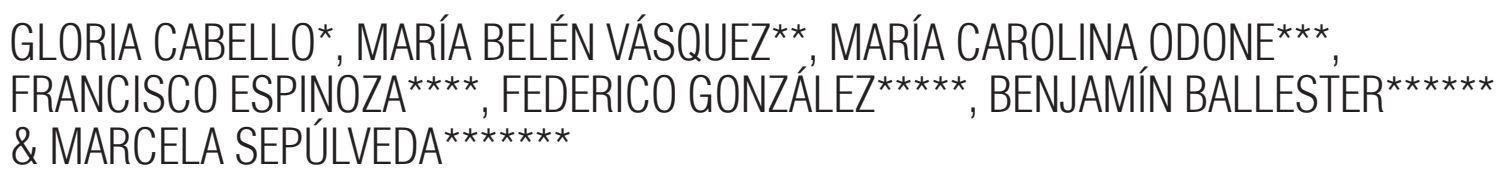

Fecha de recepción: 15 de enero de 2019 - Fecha de aprobación: 26 de noviembre de 2019

\section{Resumen}

El arte rupestre y las rutas de circulación sirven de insumo para comprender la precordillera de la región de Tarapacá como un espacio de conectividad regional y de encuentro entre las localidades de Mamiña, Quipisca e lquiuca. Desde una perspectiva transdisciplinaria en la que se funden la arqueología, la historia y la etnografía, esta investigación aborda los petroglifos, los geoglifos y la vialidad desde el estudio de la cultura material, los documentos históricos, la memoria oral y la percepción de las comunidades y las asociaciones indígenas locales. Se impone así un esfuerzo por dotar de sentido, valor e historicidad un territorio vigente y cotidiano, compuesto de elementos materiales que, si bien fueron construidos en épocas remotas, siguen siendo parte del paisaje cultural de quienes lo viven hoy.

Palabras clave: arte rupestre; vialidad; historicidad; norte de Chile.

\section{Abstract}

Rock art and circulation routes serve as inputs to understand the premountain territory of Tarapacá, as a landscape of regional connectivity and encounters between Mamiña, Quipisca and lquiuca localities. From a transdisciplinary approach that merges together the archaeology, history and ethnography, this investigation address petroglyphs, geoglyphs and the road system from the study of the material culture, historic documents, oral memory, and local perspectives from the indigenous communities and associations. An effort to provide meaning, value and historicity to an active and daily territory, composed by material elements that although they were constructed in remotes times, they are still part of the cultural landscape of those who still live it.

Keywords: rock art; roads; historicity; northern Chile.

* Dra. en Arqueología. Posdoctorante en el Instituto de Estética e Investigadora del Centro Interdisciplinario de Estudios Interculturales e Indígenas (CIIR), Pontificia Universidad Católica de Chile, Santiago, Chile. FONDECYT № 3190479 y №1181829, FONDAP № 15110006. Correo-e: glcabello@gmail.com

** Antropóloga Social. Doctorante en Antropología en la Universidad de Tarapacá. Investigadora independiente, Iquique, Chile. Correo-e: belenvasquezs@gmail.com

*** Dra. en Historia. Académica Planta Adjunta del Instituto de Historia, Pontificia Universidad Católica de Chile, Santiago, Chile. Correo-e: modoneco@uc.cl

**** Arqueólogo. Investigador independiente, Arica, Chile. Correo-e: franciscolivier.espinoza@gmail.com

****Arqueólogo. Programa de Posgrado en Antropología, Universidad de Tarapacá, Arica, Chile. Correo-e: federicogonzalezestefane@gmail.com

***** Mtr. en Arqueología de la Prehistoria y la Protohistoria. Doctorante Contractual UMR 7041 ArScAN, Équipe Ethnologie Préhistorique, Université Paris 1 Panthéon Sorbonne, París, Francia. Correo-e: benjaminballesterr@gmail.com

****** Dra. en Prehistoria, Etnología y Antropología. Escuela de Antropología, Pontificia Universidad Católica de Chile, Chile \& UMR 8096 LAMS (CNRS-Paris 1), Francia. Correo-e: marcelaasre@gmail.com 
El desierto de Tarapacá es conocido por la abundancia y la variedad de su arte rupestre, en el que destacan los geoglifos por su tamaño y visibilidad, los cuales, junto a una importante cantidad de petroglifos, han sido interpretados por su significativa participación en la red vial regional (Núñez \& Briones, 1967-1968; Núñez, 1976, 1985; Briones \& Espinoza, 1991; Chacama \& Briones, 1996; Moragas, 1996; Clarkson \& Briones, 2001; Briones, Núñez \& Standen, 2005; Briones, 2006; entre muchos). Estas obras visuales y otros arreglos de cultura material asociados a rutas -como apachetas, líneas de piedra, hitos demarcatorios, oquedades o montículos realizados en la superficie natural del suelo, algunos de ellos con ofrendas- serían el resultado de prácticas simbólicas inherentes a la circulación de personas y bienes durante las travesías por los distintos ambientes y paisajes del desierto (Pimentel, 2009, 2012; Cabello \& Gallardo, 2014; Gallardo, Cabello \& Pimentel, 2018).

La identificación de atributos formales y de motivos en petroglifos, geoglifos y otros soportes arqueológicos (textil, cestería, metal, madera y hueso) de las regiones de Tarapacá y Atacama da cuenta de un estilo visual compartido que se mantuvo vigente al menos entre el período formativo (1500-800 d.C.) y los tiempos coloniales (ca. 1600 d.C.), y con el cual se materializó la interacción entre entidades sociales de distintas localidades de la región y de áreas vecinas (Montt, 2005; Pimentel \& Montt, 2008; Gallardo, Cabello, Pimentel, Sepúlveda \& Cornejo, 2012; Berenguer, 2013; Cases \& Montt, 2013). En consonancia con la intensidad del tráfico interregional desarrollado durante el período intermedio tardío (1000-1400 d.C.), las imágenes fluyen activamente y se plasman en una gran cantidad de sitios rupestres en torno al sistema vial, pero también en contextos habitacionales de esa época. Así, esta red de relaciones incorpora tanto el ámbito público como el doméstico y privado (Núñez, 1965a, 1965b; Mostny, 1970; Chacama \& Espinosa, 1997; Chacama, 2003; Vilches \& Cabello, 2011).

Este artículo ofrece nuevos datos a estas interpretaciones a partir de una investigación sobre arte rupestre y rutas de movilidad en el área de influencia de la Compañía Minera Cerro Colorado $(\mathrm{CMCC})^{1}$. El estudio contempló el registro y el análisis de petroglifos, geoglifos y otros elementos materiales asociados a rutas (líneas de piedra, estructuras habitacionales, hitos demarcatorios) entre las localidades de Mamiña, Quipisca e lquiuca (Figura 1). El objetivo de la investigación fue evaluar la función social de estos registros arqueológicos y su variabilidad a lo largo de la historia, desde tiempos prehispánicos hasta la actualidad, a través de una metodología transdisciplinaria que consideró tres dimensiones: arqueológica, histórica y etnográfica. Para este artículo, nos centramos en los resultados obtenidos en torno al arte rupestre, cuyo análisis estilístico, puesto en comparación con la información recabada, permite ofrecer una secuencia histórica prospectiva, diagnóstica y diacrónica, que entrega elementos de análisis y reflexión acerca de la forma en que las poblaciones locales construyeron este espacio en las épocas prehispánicas, colonial y republicana temprana, pero también de manera reciente. Si bien es un enfoque parcial y exploratorio, la información inédita y sistematizada aquí contribuye a profundizar la comprensión del uso y la configuración de este espacio en una región con una larga historia ocupacional (Santoro, Capriles, Gayó, De Porras, Maldonado, Standen, Latorre, Castro, Angelo, McRostie, Uribe, Valenzuela, Ugalde \& Marquet, 2017). 
Figura 1. Mapa general con la ubicación del área y los sitios arqueológicos de este estudio

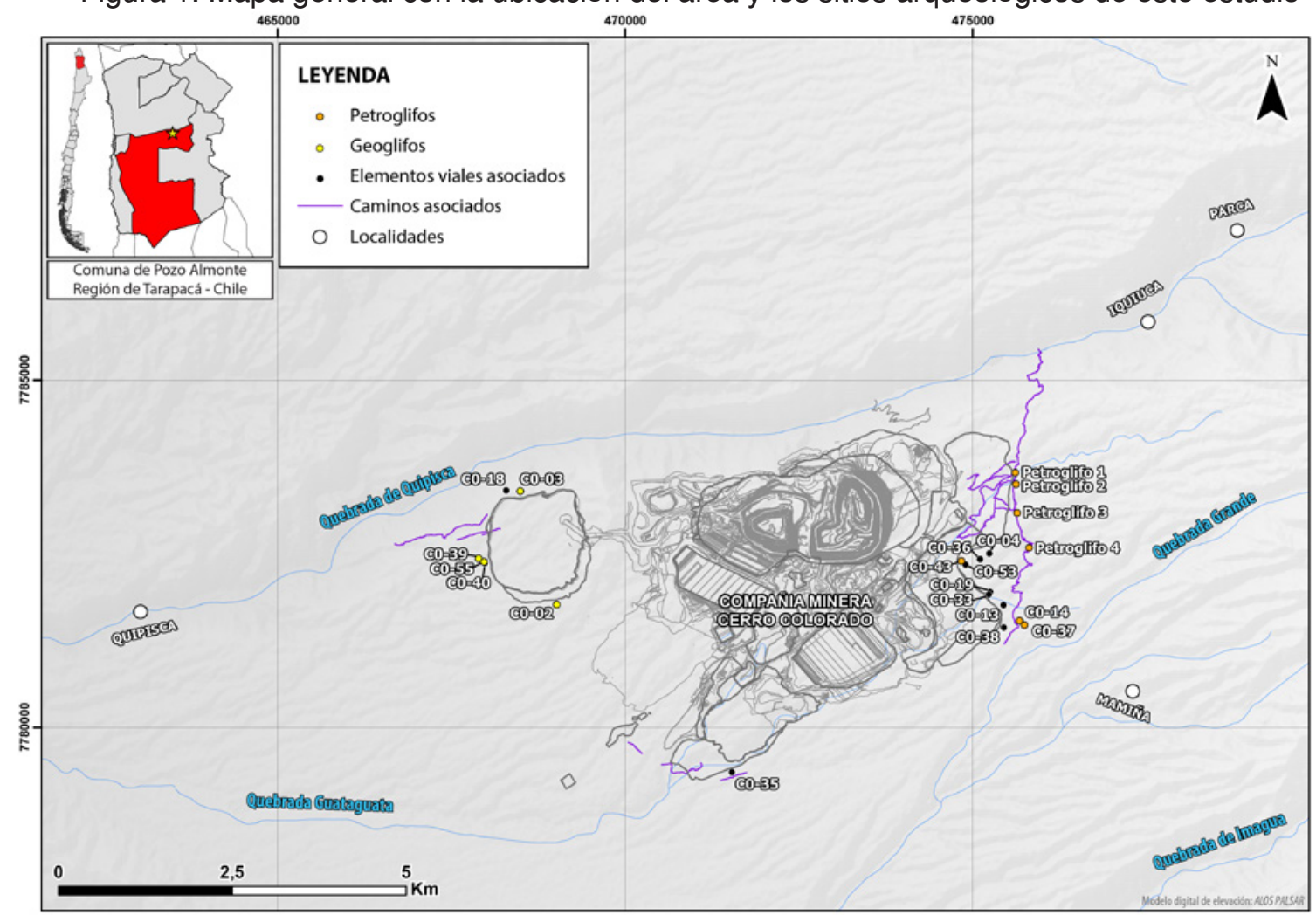

(Elaboración propia con base en el modelo digital ALOS PALSAR)

Quisiéramos destacar que esta investigación surge del interés por re/conocer su territorio por parte de la Comunidad Indígena Quechua de Quipisca (CIQQ), la Comunidad Indígena Quechua de Mamiña (QIQM), la Comunidad Indígena Quechua de lquiuca (CIQI), la Asociación Indígena Aymara Kespi Kala de Mamiña (AIAKK) y la Asociación Indígena Aymara Cuenca de Quipisca (AIACQ). Esperamos que nuestra lectura sirva a la puesta en valor de estas expresiones materiales y de los esfuerzos de sus antepasados por lograr conectividad entre espacios distantes y diversos, así como su empeño en hacer posible la comunicación y la colaboración entre los actores sociales de la inmensa red de relaciones económicas, sociales y simbólicas que se tejen hoy en esta porción del desierto tarapaqueño.

\section{Acerca de los geoglifos, petroglifos y rutas de tránsito en Tarapacá}

La relación entre sitios de arte rupestre (petroglifos y geoglifos) y caminos troperos o de caravanas ha sido ampliamente documentada en todo el desierto de Atacama (Bollaert, 1860; Niemeyer, 1961; Mostny \& Niemeyer, 1983; Cerda, Fernández \& Estay, 1985; Moragas, 1996; Rivera \& Clarkson, 1997; Clarkson, 1999; 
Clarkson \& Briones, 2001; Cabello, Gallardo \& Odone, 2013; además de los ya citados) $)^{2}$. Rutas que en su inicio parecían más o menos estandarizadas se fueron convirtiendo en una amplia red vial integrada por múltiples comunidades, incluso más allá de las cumbres cordilleranas (Berenguer, 1994, 1995; Nielsen, 1997, 2006; Berenguer \& Pimentel, 2010, 2017). Junto a los caminos, y como parte del sistema vial, se levantaron, además, diversas estructuras que implicaron una inversión de trabajo para su producción, mantención y resguardo, como campamentos de descanso o paskanas, apachetas ${ }^{3}$, muros y cajitas, líneas de piedra, petroglifos, geoglifos y otros tipos de marcas y ofrendas (Sinclaire, 1994; Lynch, 1995-1996; Nielsen, 1997-1998; Berenguer, Cáceres, Sanhueza \& Hernández, 2005; Briones et al., 2005; Berenguer \& Cáceres, 2008; Correa \& García, 2014; Berenguer \& Salazar, 2017).

Estos arreglos visuales en las rutas por donde circularon personas $-y$ con ellas ideas, conocimientos, bienes, productos y materias primas- se convirtieron en ejes articuladores del paisaje y también de los vínculos y las relaciones entre colectivos humanos, distantes 0 cercanos. Bajo esta perspectiva, las interpretaciones que proponen que los petroglifos y los geoglifos constituyen señales camineras (indicativas de puntos de encuentro y conexión, de lugares productivos o de culto) se integran con aquellas que vinculan su producción y consumo con ritos que sacralizan los lugares de tránsito y los distintos sectores productivos relacionados con el tráfico interregional, tal y como ocurre con las apachetas, donde se realizan ceremonias en las que son depositadas hojas de coca y otras ofrendas (Bollaert, 1860; Niemeyer, 1961; Núñez, 1965b; Mostny, 1970; Galdames, 1990). Esta diversidad funcional es refrendada en la convivencia de representaciones de "cultos de animales [algunos exóticos como 'simios'], shamanísticos, sacrificios, bailes rituales [personajes vestidos, que portan hachas o que combinan atributos humanos y animales, a veces en actitud dinámica junto a otros], guerras simbólicas [arqueros frente a pescador] y tráfico [caravanas de llamas]" (Núñez, 1965b, p. 115). Todo ello da cuenta no solo de la dinámica cultural y económica acaecida entre distintas comunidades que habitaron los ambientes de la región (Núñez \& Briones, 1967-1968), sino también de la necesaria reducción de sus diferencias sociales y culturales mediante una identidad visual común a todos los que circulaban por esos caminos (Gallardo, Cabello \& Pimentel, 2018).

Frente a estas interpretaciones, uno de los aspectos más complejos de abordar es la precisión de la antigüedad exacta de las vías y por cuánto tiempo estuvieron en uso, así como los grupos que las emplearon, pues -como todo sitio arqueológico- son consecuencia de la suma de eventos a lo largo del tiempo y su definición requiere necesariamente de la correlación de diversas fuentes. Una de las formas tradicionales de adscribir tentativamente su temporalidad ha sido el estudio de sus elementos asociados, como la iconografía de los geoglifos y los petroglifos, las tipologías de los fragmentos cerámicos, los materiales recuperados de sus paskanas o las tumbas de los fallecidos enterrados junto a las rutas (Clarkson, 1996; Muñoz \& Briones, 1996; Berenguer et al., 2005; Uribe \& Cabello, 2005; Valenzuela, Briones \& Santoro, 2006; Valenzuela, Santoro \& Briones, 2011; Cases, Rees, Pimentel, Labarca \& Leiva, 2008; Pimentel, Rees, De Souza \& Ayala, 2010; Pimentel, Rees, De Souza \& Arancibia, 2011). 
De esta manera, la datación absoluta de una niña de origen costero enterrada junto a una mujer de igual origen, cerca de los geoglifos y los paskanas en los faldeos de Cerro Mono, sitúa la ruta que conecta la costa con los valles interiores hacia fines del período arcaico tardío e inicios del formativo (Briones et al., 2005) ${ }^{4}$. Sabemos que en esa época de intensificación económica, creciente sedentarismo y complejidad social, poblaciones de las distintas ecozonas del perfil costa-altiplano se congregaron eventualmente en aldeas de las quebradas de Tarapacá (Pircas y Caserones) y Guatacondo (Ramaditas y G-1) para realizar actividades colectivas en torno a la explotación de recursos forestales y agrícolas (Urbina et al., 2012). Ambas cuencas son ricas en manifestaciones rupestres asociadas a rutas viales, pero en la segunda destacan los petroglifos de Tamentica, cuya comparación iconográfica con otros soportes materiales (cerámica, cestería, metal, textiles, entre otros) sitúa sus inicios en el formativo (Cabello \& Gallardo, 2014) y su vigencia hasta el período intermedio tardío (PIT), época a la cual se vincula la mayoría de la producción rupestre regional (Mostny \& Niemeyer, 1963; Núñez, 1965b; Núñez \& Briones, 1967-1968; Mostny, 1970; Chacama \& Briones, 1996).

En ese momento, la especialización y el aumento productivo en los distintos espacios ecológicos de la región impulsaron el desarrollo de colectividades económicamente independientes, que intercambiaban sus excedentes gracias a grupos caravaneros que circulaban por antiguas y nuevas rutas (Uribe, Sanhueza \& Bahamondes, 2007). La intensificación de la agricultura promueve la ocupación de las quebradas interiores con grandes asentamientos en Camiña (Camiña 1, Chusmisa, Ñama 1) y Tarapacá (Carora y Tarapacá Viejo o Tr-49) y
Mamiña (Jamajuga o Cerro Gentilar). Su identidad se expresa a través de distintivas cerámicas y prendas textiles, que arqueológicamente se agrupan y definen en el Complejo Pica-Tarapacá (Niemeyer, 1961; Núñez, 1965b; Uribe et al., 2007). La presencia de grabados rupestres en recintos habitacionales de algunos de estos sitios y las dataciones absolutas realizadas sobre los geoglifos del cerro Challacollito y quebrada Los Pintados sostienen su atribución al PIT (Clarkson \& Briones, 2001; Vilches \& Cabello, 2011) ${ }^{5}$.

Alrededor del año 1400 d.C., al igual que muchas poblaciones de los Andes, los habitantes locales debieron adecuarse a nuevas fórmulas de organización económica y social promovidas por el Tawantinsuyu, que dio inicio al período tardío (PT) o incaico (1400-1570 d.C). El incremento en la producción, la introducción de nueva tecnología, la diversificación en los bienes y los productos de interés, la promoción de autoridades locales, entre otras innovaciones, dejó improntas en la decoración cerámica, la arquitectura y el arte rupestre por todo el norte de Chile (Berenguer, 2013; Troncoso, 2011; Cases \& Montt, 2013). En Tarapacá se observan estructuras incaicas en muchos de los sitios previos ( $\mathrm{Tr}-49$ ) o los nuevos asentamientos junto a ellos (Incaguano o Incamarca) y explotaciones mineras (Collawasi 37), entre las que destaca el enterratorio ritual (capaqcocha) en Cerro Esmeralda, frente a Huantajaya, cuyo mineral de plata pudo comenzar a explotarse en esa época (Uribe y Sánchez, 2016). De igual manera, parte de las rutas se anexan a la extensa red vial del Qhapaq Ñan, tanto en sus ramales principales, que iban de norte a sur, como de los que se desprendían hacia la costa por las quebradas o el interfluvio (Berenguer et al., 2005; Zori \& Urbina, 2014; Berenguer \& 
Salazar, 2017; Zori \& Brant, 2017; y en especial Zori, Brant \& Uribe, 2017, Fig. 2).

Luego de la incorporación de la región a la organización político-administrativa y económico-social colonial del Tenientazgo o Partido de Tarapacá en 1565, se siguieron utilizando prácticamente las mismas rutas para transportar maíz, guano, algodón, pescado seco y recursos mineros desde los espacios productivos tradicionales (Larraín, 1975; Villalobos, 1979). Por toda el área andina se reconocen grabados, incisos, pinturas y, en menor medida, geoglifos de la época colonial: jinetes montados a caballo a veces en escenas de enfrentamiento, cruces cristianas de diversos tipos, calvarios, campanarios de iglesia, escenas de procesión e incluso barcos (Núñez \& Briones, 1967-1968; Gallardo, Castro \& Miranda, 1990; Moragas, 1996; Arenas \& Martínez, 2007, 2009; Arenas, 2013; González, 2014; Arenas \& Odone, 2015). La superposición de algunas de estas manifestaciones sobre motivos de origen claramente prehispánico ha sido interpretada como producto de la extirpación de idolatrías durante el proceso de evangelización en los Andes, aunque el predominio de su copresencia permite, alternativamente, proponer la continuidad de una práctica indígena que incorpora, reconfigura y resignifica la iconografía occidental (Martínez, 2009; González, 2014; Arenas \& Odone, 2016; Gallardo, 2018).

Aunque los estudios históricos específicos para el interfluvio de Cerro Colorado son más bien escasos, se reconoce que los habitantes indígenas de Quipisca, Mamiña e lquiuca participaron de las dinámicas de organización político-administrativa y económico-social colonial: la inserción en el sistema de encomiendas de Tarapacá/Pica/Loa, el nucleamiento en pueblos de indios y la reorganización de los poderes de las autoridades locales o kurakas. A partir de la segunda mitad del siglo XIX los poblados de Quipisca y Mamiña, con mayor concentración de población y disponibilidad hídrica, fueron centrales en suministrar recursos y productos a oficinas salitreras de los cantones de Pozo Almonte, La Noria, Alto San Antonio y Huara: Mapocho, Peña Grande y Chica, Don Guillermo, Cala-Cala, Huara, incluso Humberstone. A partir de las décadas de 1930 y 1940, coincidiendo con la caída del auge salitrero, se producen paulatinos desusos, abandonos y desestructuraciones de esos espacios habitados y de la tradicional circulación por las rutas (Bollaert, 1860; Solano, 1867; Billinghurst, 1886; Risopatrón, 1924; Niemeyer, 1961; González, 1989; Espinoza, 2013 (1897); Larraín, 2012; González \& Artaza, 2013; Olmos, Capetillo, Riffo \& Pinto, 2018).

Los estudios arqueológicos en este sector son aún más limitados (Niemeyer, 1961; Briones \& Espinosa, 1991), aunque en los últimos doce años se han incrementado los registros a partir de proyectos vinculados con el cumplimiento de la legalidad ambiental (Moragas, Briones, Carrasco, Ajata, Rocha \& Contreras, 2006; JIA, 2013; Loyola, 2013; Westfall \& Vargas, 2015; Capetillo \& Navarro, 2016; Yakuba, 2016). Esos estudios reconocen gran cantidad de senderos y huellas troperas vinculados a estructuras de piedra, paskanas, petroglifos y geoglifos. En su conjunto conforman un complejo entramado vial que une las principales localidades inmediatas al sector de Cerro Colorado ${ }^{6}$. Sin embargo, la atribución temporal al PIT y el PT se ha establecido solo para unos pocos de estos sitios, lo que restringe la posibilidad de reconstruir una secuencia histórica y visual para el área de estudio. 
El progresivo interés de las comunidades en la recuperación patrimonial de su territorio ha impulsado iniciativas que aportan mayores antecedentes sobre cómo se fue configurando este espacio a lo largo del tiempo (Estica, 2006; Larraín, 2012; CIQQ, 2014, 2016, 2017a, 2017b; CIQM, 2016). Por ejemplo, en torno a la quebrada de Quipisca existen evidencias arqueológicas del período arcaico y el formativo, estructuras habitacionales y agrícolas ocupadas durante el PIT y el PT (La Capilla, Taypimarka, La Palma, Tauquinza), y vestigios de la pequeña producción minera desde el período colonial en adelante (Larraín, 2012; CIQQ, 2017a). También hay petroglifos en contextos domésticos, productivos, funerarios y viales (Accha, Angostura, Liacsa, Dupliza); un tramo del Qhapaq Ñan y otros sistemas de caminos con numerosos geoglifos asociados al PIT, el PT y la Colonia, algunos de los cuales conectan Quipisca con la quebrada de Tarapacá y Mamiña, y otros con los cerros considerados sagrados por las actuales comunidades indígenas (Cerro Colorado, Cerro Negro, Wata Watana, Loma Negra) (CIQQ, 2017a). Ello nos indica una continuidad en el uso de este paisaje desde tiempos prehispánicos hasta hoy, como bien lo ilustran los libros editados por Larraín (2012) y Olmos et al. (2018). En ellos se exploran los múltiples usos y valores sociales contemporáneos de las rutas entre Quipisca, Mamiña, Macaya y Pica, respectivamente, desde una perspectiva que une la memoria local, la historia y la arqueología.

\section{Área de estudio y metodología de investigación}

El área de estudio corresponde a un sector de interfluvio y quebradas intermedias de la región de Tarapacá entre los 2.000 y 3.000 msnm. Las localidades que circundan el área son Quipisca, lquiuca, Parca y Mamiña, todas emplazadas en lechos de valles y quebradas. Mamiña se extiende, además, a sectores de relieve entre quebradas. La investigación se focalizó en los 22 sitios involucrados en las Medidas de Compensación, los cuales se distribuyen en los límites oriente y poniente del área de influencia de la CMCC, cuya superficie total corresponde a $30 \mathrm{~km}^{2}$, que incluye zonas de quebradas, planicies, montes y cerros (Figura 1).

Para desarrollar la investigación se implementaron cuatro estrategias metodológicas. La primera fue la revisión de fuentes documentales relativas a la arqueología y la historia (publicaciones, documentos, informes y archivos inéditos) para relevar la información existente acerca del arte rupestre, las rutas, la cultura material, los aspectos etnográficos y la historia de las comunidades del área de estudio.

La segunda estrategia consistió en el análisis en terreno del arte rupestre, tanto petroglifos como geoglifos, para conocer, a nivel cuantitativo y cualitativo, el universo de estudio y poder ahondar en los diferentes tipos de motivos, principales atributos, emplazamiento, técnicas de manufactura y asociaciones con otros elementos arqueológicos. Para el registro en terreno se emplearon fichas previamente elaboradas, atingentes a cada clase de motivo, junto con dibujos a escala de cada uno de ellos, vuelos de drones y levantamientos topográficos de precisión submétrica de los sitios. 
En tercer lugar, se emprendió una etapa de fotointerpretación que involucró la inspección sistemática de fotografías satelitales (disponibles en Google Earth y Bing Maps) para realizar tres tipos de análisis: locacional, que busca comprender la prominencia topográfica y las pendientes; de visibilidad ${ }^{7}$, que permite calcular la visibilidad desde los caminos y evaluar su relación con los sitios de geoglifos y petroglifos en estudio; y distribucional, que evalúa la distribución y la conectividad de estos caminos más allá del área de influencia de la CMCC. Para esto se definieron como límites las quebradas de Tarapacá por el norte y de Macaya por el sur, y las localidades de Noasa por el este y de Caiuga por el oeste, y se creó una grilla de 1.575 cuadrículas de $1 \mathrm{~km}^{2}$ inspeccionadas individualmente. En los análisis se empleó un modelo de elevación digital ALOS PALSAR (12,5 m/píxel). Para los geoprocesos se utilizó la herramienta ESRI "Spatial Analyst" y "Land Facet Corridor Designer" (Weiss, 2001), y para la cercanía a los caminos, la herramienta ESRI "Near", bajo la consideración de un buffer de 200 metros.

Finalmente, a través de una metodología etnográfica se relevaron aspectos cualitativos de los saberes simbólicos y prácticos en relación con el arte rupestre y las rutas de movilidad que poseen las comunidades y las asociaciones indígenas locales vinculadas al proyecto (CIQQ, CIQM, CIQI, AIAKK y AIACQ). Esta información fue recabada de forma independiente con cada una de las organizaciones, mediante reuniones de acercamiento, terrenos de reconocimiento de sitios arqueológicos y sectores de cultivo, focus groups o entrevistas grupales y conversaciones con actores claves. En instancias separadas se presentaron los resultados, los cuales fueron validados y finalmente entregados a través de un informe técnico particular.
Cada una de estas estrategias generó una información cuantiosa sobre el arte rupestre y las vías de comunicación en el área de estudio. En este artículo se presenta solo una pequeña parte de sus resultados.

\section{Nuevos registros en torno al Cerro Colorado}

\section{Petroglifos}

Se trabajó en seis sitios, todos ubicados en el límite oriente de la CMCC, más o menos distantes, y a ambos costados de la ruta A-639 que une actualmente Mamiña con lquiuca y Parca, territorio que es reconocido como patrimonio por las comunidades indígenas CIQI y CIQM. En el marco de esta investigación se relevaron 72 paneles, correspondientes a 65 bloques rocosos erráticos, de tamaño mediano a pequeño (algunos incluso muebles), entre los que se distribuyen diferencialmente los registrados, destacando CO-43, que concentra 58,3\% de la muestra (Tabla 1). En total se identificaron 190 motivos ( $\mathrm{N}=130$ en $\mathrm{CO}-43 ; 68,4 \%$ del universo), en su mayoría ejecutados mediante la técnica de piqueteado de forma exclusiva $(71,5 \%)$ o bien combinada con el uso de incisos y/o raspados $(22,5 \%)$ en ciertos sectores de las figuras. Los motivos por incisión o raspado mayoritario constituyen $10,9 \%$ de la muestra y se hallan solo en los sitios con mayor cantidad de paneles, donde se observaron, además, incisiones irregulares en soportes con o sin figuras, que no fueron registradas porque no constituyen motivos en sí. 
Tabla 1. Representación del arte rupestre por sitio

\begin{tabular}{|c|c|c|c|c|c|c|c|c|}
\hline & Sitio & Paneles & Motivos & \multirow{14}{*}{ 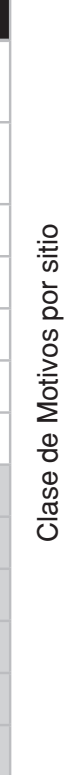 } & Antropomorfo & Zoomorfo & Geométrico & Total \\
\hline \multirow{7}{*}{ 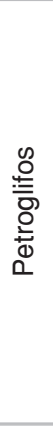 } & $\mathrm{CO}-43$ & $\begin{array}{c}42 \\
(58,3 \%)\end{array}$ & $\begin{array}{c}130 \\
(68,4 \%)\end{array}$ & & $14(10,7 \%)$ & $20(15,3 \%)$ & $96(73,8 \%)$ & $130(100 \%)$ \\
\hline & $\begin{array}{c}\text { CO-14 y } \\
\text { CO-37 }\end{array}$ & $\begin{array}{c}16 \\
(22,2 \%)\end{array}$ & $31(16,3 \%)$ & & $2(6,4 \%)$ & $4(12,9 \%)$ & $25(80,6 \%)$ & $31(100 \%)$ \\
\hline & Petroglifo 1 & $3(4,1 \%)$ & $3(1,5 \%)$ & & $1(33,3 \%)$ & 0 & $2(66,6 \%)$ & $3(100 \%)$ \\
\hline & Petroglifo 2 & $6(8,3 \%)$ & $20(10,5 \%)$ & & $9(45 \%)$ & $1(5 \%)$ & $10(50 \%)$ & $20(100 \%)$ \\
\hline & Petroglifo 3 & $4(5,5 \%)$ & $3(1,5 \%)$ & & $1(33,3 \%)$ & $1(33,3 \%)$ & $1(33,3 \%)$ & $3(100 \%)$ \\
\hline & Petroglifo 4 & $1(1,3 \%)$ & $3(1,5 \%)$ & & 0 & $2(66,6 \%)$ & $1(33,3 \%)$ & $3(100 \%)$ \\
\hline & Total general & $72(100 \%)$ & $190(100 \%)$ & & $27(14,2 \%)$ & $28(14,7 \%)$ & 135 (71\%) & $190(100 \%)$ \\
\hline \multirow{6}{*}{ 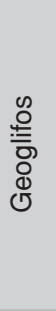 } & $\mathrm{CO}-03$ & $1(20 \%)$ & $4(36,3 \%)$ & & 0 & $1(25 \%)$ & $3(75 \%)$ & $4(100 \%)$ \\
\hline & CO-55 & $1(20 \%)$ & $1(9 \%)$ & & 0 & 0 & $1(100 \%)$ & $1(100 \%)$ \\
\hline & $\mathrm{CO}-02$ & $1(20 \%)$ & $2(18,1 \%)$ & & 0 & 0 & $2(100 \%)$ & $2(100 \%)$ \\
\hline & CO-39 & $1(20 \%)$ & $2(18,1 \%)$ & & 0 & 0 & $2(100 \%)$ & $2(100 \%)$ \\
\hline & CO-55_39 & $1(20 \%)$ & $2(18,1 \%)$ & & 0 & 0 & $2(100 \%)$ & $2(100 \%)$ \\
\hline & Total general & $5(100 \%)$ & $11(100 \%)$ & & 0 & $1(9 \%)$ & $10(90,9 \%)$ & $11(100 \%)$ \\
\hline
\end{tabular}

En cuanto a la clase de motivos ${ }^{8}$, los geométricos representan $71 \%$ de la muestra $(\mathrm{N}=135)$, siendo además los más numerosos en tres de los seis sitios (CO-43, CO-14-37 y Petroglifo 1). Consignamos también una equivalencia entre antropomorfos y zoomorfos en torno a $14 \%$ del total, aunque representados de forma desigual entre los sitios (Tabla 1). En la clase geométricos distinguimos aquellos de tipo simple $(\mathrm{N}=70$; $36,8 \%$ del total), que agrupan formas circulares, trapezoidales, lineales, grecas, puntos e indeterminados, incluyendo la representación, solo en CO-43, de letras o números, de evidente factura histórica (Figuras 2A-B, E). El tipo geométrico compuesto no simétrico $(\mathrm{N}=56 ; 29,4 \%$ de la muestra) agrupa motivos cuyos elementos se relacionan por intersección, inscripción o de forma apendicular. En este grupo existen ejemplares mixtos que combinan círculos y líneas (Figura 2C-D). Finalmente, los geométricos compuestos simétricos son más escasos $(\mathrm{N}=9$; $4,7 \%$ del total) e incluyen motivos conformados por elementos replicados por reflexión (círculos), traslación (círculos, líneas onduladas, puntos) y rotación (círculos, triángulos). Estos últimos se ubican en asociación con letras, posiblemente "cruces de malta" (Figura 2E). 
Figura 2. Petroglifos: A) CO-43-B31-Pa ( $\mathrm{CO}-14$ y CO-37-B6-Pa; E) CO-43-B34-Pa

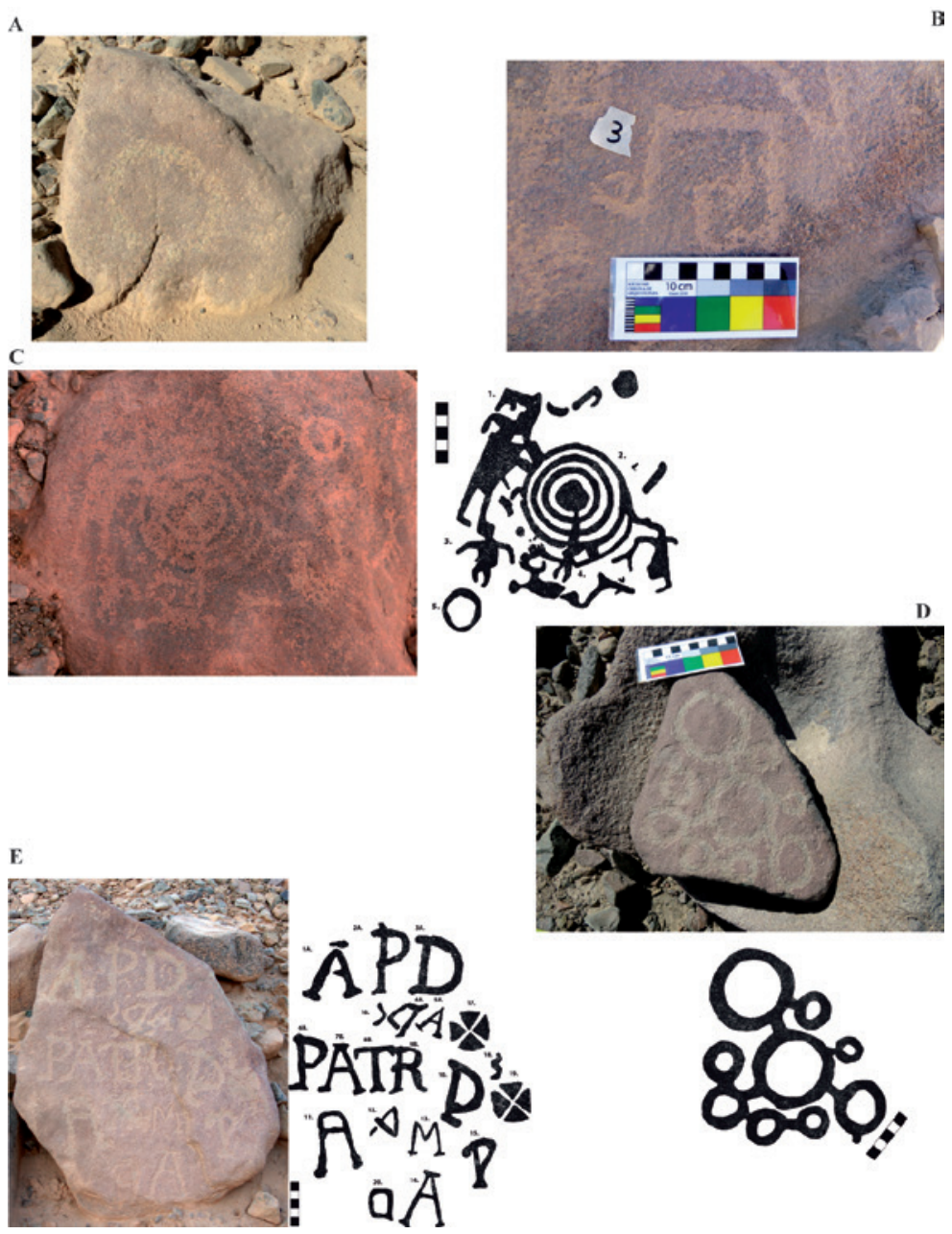

Elaboración propia, dibujos B. Brancoli.

Entre los antropomorfos ( $\mathrm{N}=27 ; 14,2 \%$ de la muestra), dos tercios son representados con indumentaria $(\mathrm{N}=18)$, principalmente con trajes tipo túnica $(\mathrm{N}=10)$, de contorno rectangular, triangular u oval, que de forma excepcional poseen diseños en su interior (Figura 3). La mitad de estas figuras exhiben, además, tocados y/u otros elementos que pueden identificarse como hachas, arco/flecha y lazo o cola de un "hombre-pájaro" (respectivamente Figuras 3C-D M3 y M5, E M4). En otros casos, la indumentaria está compuesta solo de tocados
$(\mathrm{N}=7)$, uno de los cuales posee una figura circular en las manos identificada como una cabeza cortada. Finalmente, existe un motivo antropomorfo de perfil, que posee una figura triangular vacía con apéndices lineales adosada a la espalda (Figura 3D M12A). El tercio restante corresponde a antropomorfos simples $(\mathrm{N}=9)$, es decir, que exhiben solo los atributos básicos de un ser humano (cabeza, tronco y extremidades), sin elementos extrasomáticos (traje u objetos en las manos). 
Figura 3. Petroglifos: A) Petroglifo 3-B3-Pa; B) Petroglifo 1-B01-Pa;

C) CO-14 y CO-37-B3-Pa; D) Petroglifo 2-B01-Pa; E) CO-43-B22-Pa
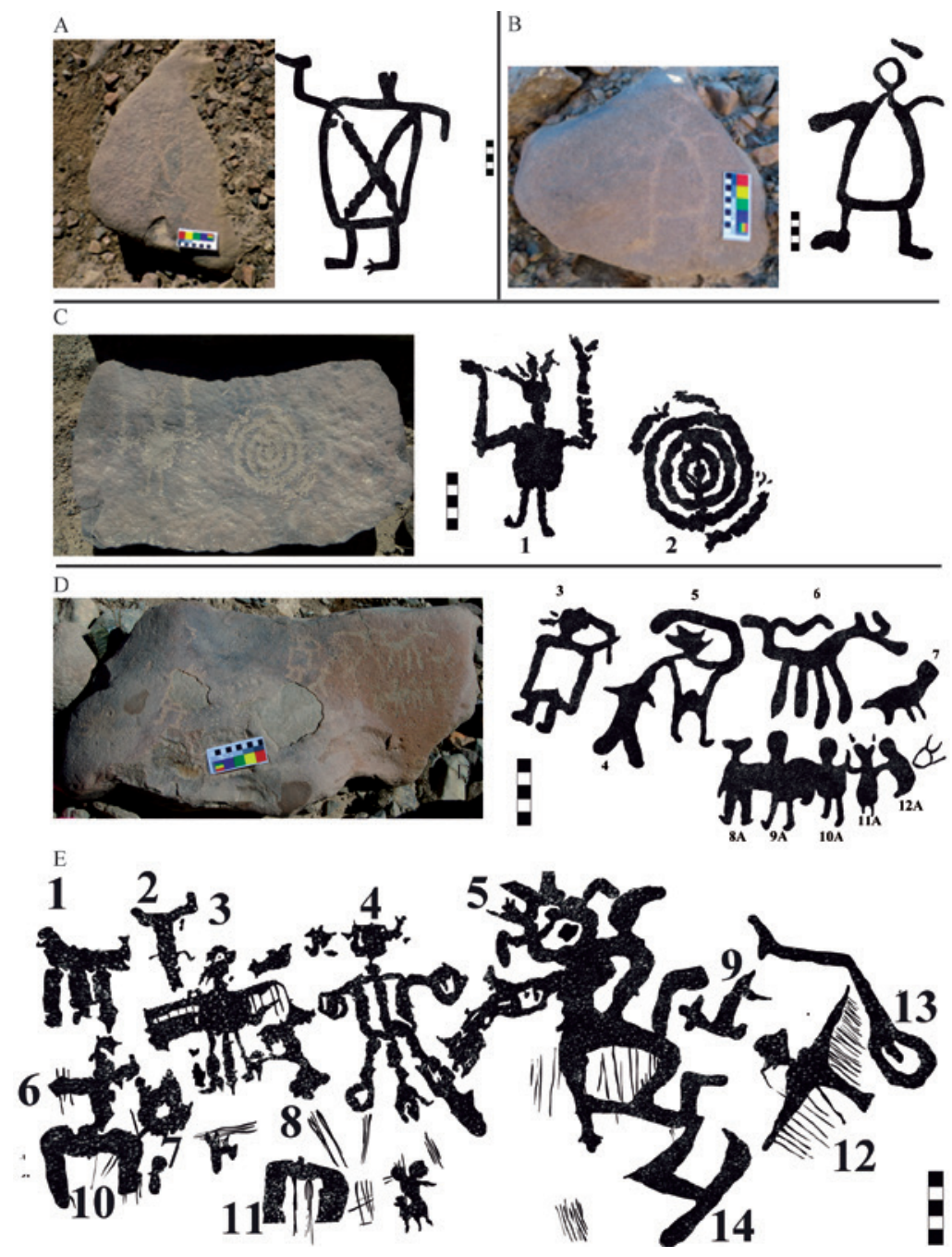

Elaboración propia, dibujos B. Brancoli.

En la clase zoomorfa ( $\mathrm{N}=28 ; 14,2 \%$ del total) distinguimos camélidos $(\mathrm{N}=17)$, aves $(\mathrm{N}=7)$, lagartijas $(\mathrm{N}=2)$, un batracio y un tridígito. Los camélidos muestran gran variedad en su diseño, aunque son representados casi exclusivamente de modo simple (Figura 4A-D), salvo dos casos en que presentan aparentes lazos al cuello en composiciones escénicas (ver infra). Las aves también cuentan con un diseño variado, siendo todos ejemplares únicos. A partir de sus atribu- tos formales distinguimos cóndores (Figuras 3E M12 y 4C-E) y ñandús, avestruz cordillerana o suri (Figura 4F-G). La presencia en un mismo panel de camélidos y aves es recurrente (3 paneles de CO-43 y 1 de Petroglifo 4, Figura $4 C-D)$, aunque no se perciben relaciones compositivas. Las lagartijas y el tridígito también comparten panel con un camélido (Figura 4H), mientras que el batracio es el único motivo de un panel del mismo sitio (Figura 4I). 
Figura 4. Petroglifos: A) CO-14-37-B13-Pa; B) CO-14 y CO-37-B02-Pa; C) Petroglifo 4-B01-Pa; D) CO-43-B03-Pa; E) CO-43-B10-Pa; F) Petroglifo 3-B4-Pa; G) CO-14 y CO-37-B15-Pa;

H) CO-43-B15-Pa; I) CO-43-B08

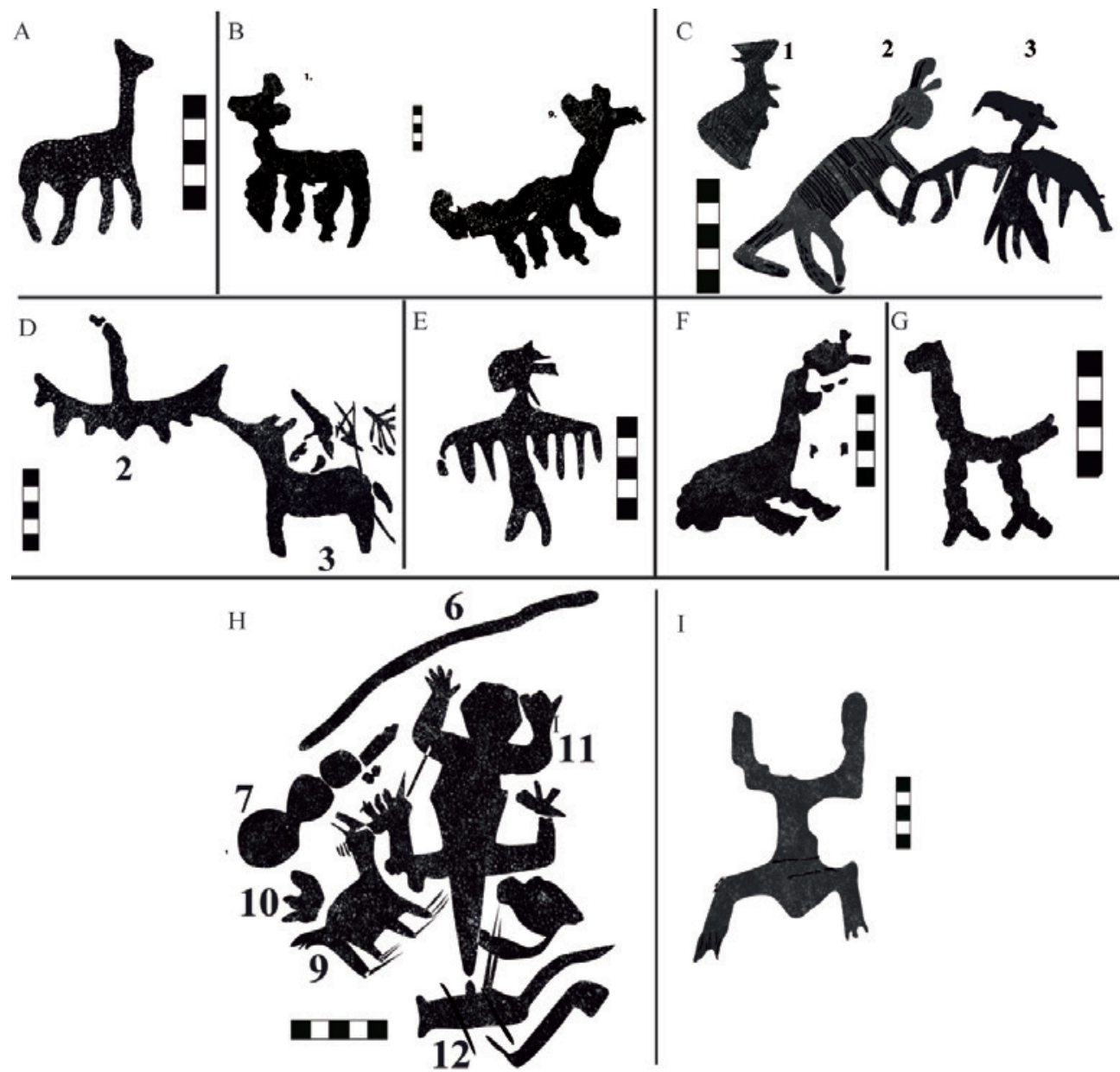

Elaboración propia, dibujos B. Brancoli.

Se reconocieron tres composiciones entre los motivos, todas de tipo escénico: una con cinco antropomorfos unidos, algunos con vestimenta rectangular (Figura 3D M8A-12A); otra con dos antropomorfos con tocado, de perfil enfrentado y entrelazados, posiblemente en acto sexual (Figura 5B M1A-2A); y una escena de caravana con cuatro camélidos de perfil derecho enla- zados a un antropomorfo (Figura 5A M2A-7A). En esta última representación, los camélidos poseen diseños distintos, lo que si bien es consecuente con la variedad formal de este tipo de figuras registrada en los distintos sitios, en el caso de una composición podría ser indicativo de diferencias temporales o de autor. 
Figura 5. Petroglifos: A) CO-43-B32-Pa; B) CO-43-B28-Pa
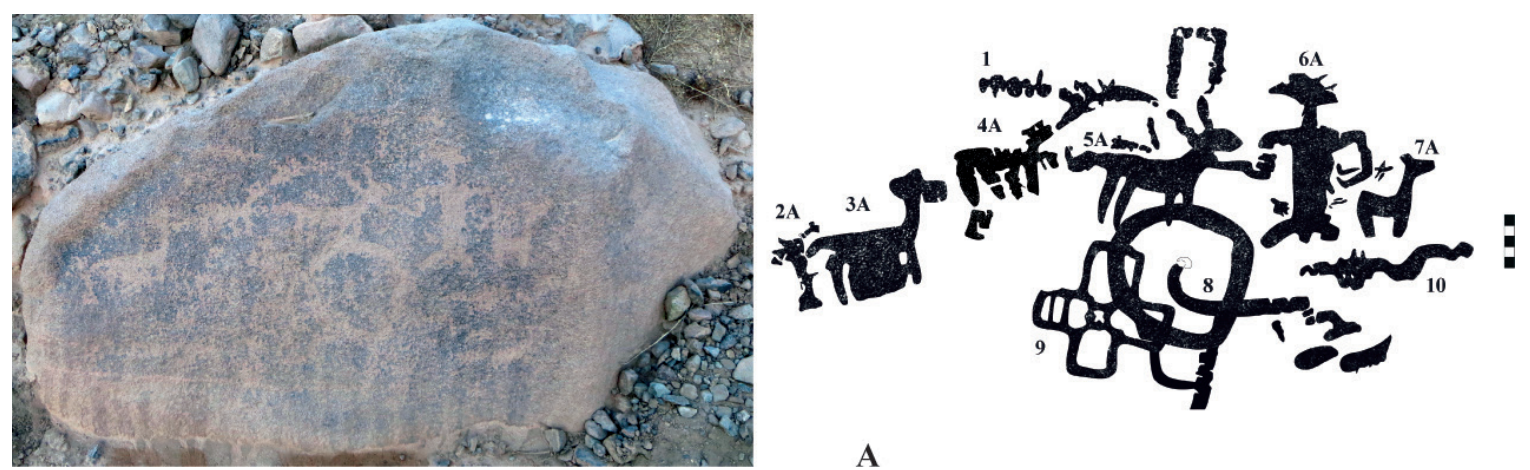

A
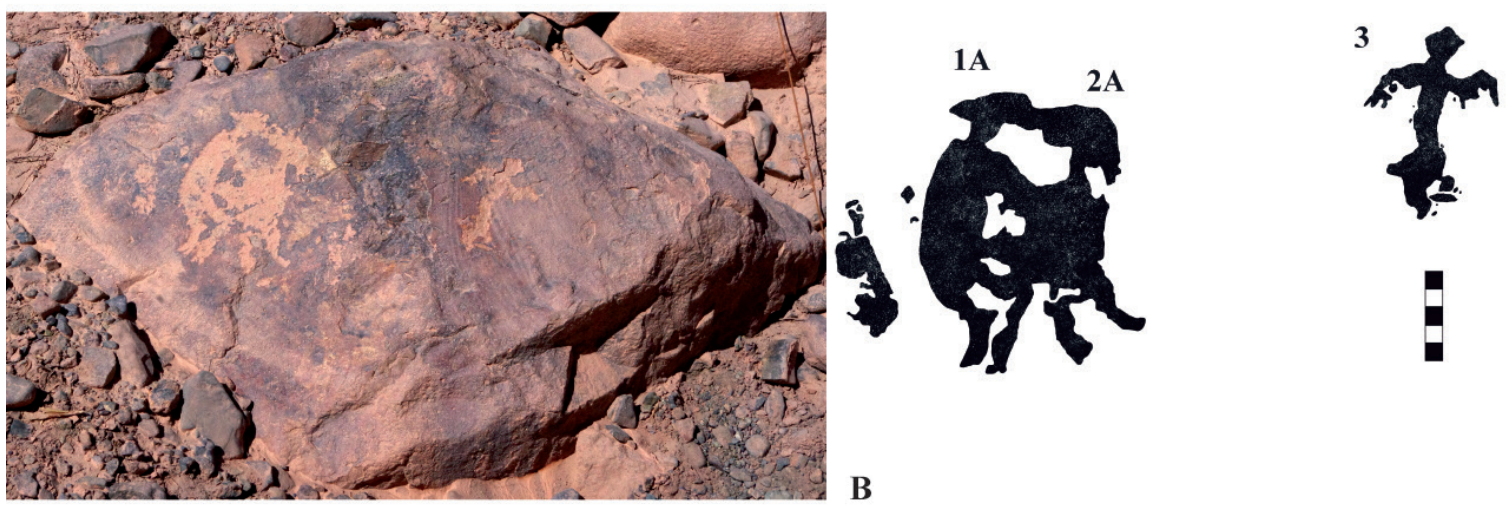

Elaboración propia, dibujos B. Brancoli.

Finalmente, se distinguieron 21 motivos superpuestos, 19 de ellos en seis paneles de CO-43 y dos más en un panel del sitio Petroglifo 4 , vinculados principalmente a la clase geométrica $(\mathrm{N}=12)$ y a los zoomorfos $(\mathrm{N}=8)$, con un solo caso de antropomorfo. Salvo este último, que se halla bajo un geométrico compuesto no simétrico (zigzag con apéndices, Figura 3E M5 y M14), las superposiciones comprenden, en general, motivos de una misma clase, por ejemplo, entre letras, camélidos, geométricos apendiculares bajo inscritos o por rotación. En cuanto a las técnicas de ejecución, resulta interesante que la mayoría de los motivos inferiores fueron confeccionados solo por piqueteado
( $\mathrm{N}=8$ ) o con esta técnica más incisos y/o raspados que complementan o transforman el diseño original (p. e., plumas en las alas o garras en las patas, Figuras 3E M12 y $5 \mathrm{H} \mathrm{M9).} \mathrm{A} \mathrm{ellos}$ se sobreponen motivos con técnicas combinadas $(\mathrm{N}=5)$ o exclusivas (piqueteado $\mathrm{N}=3$, inciso $\mathrm{N}=1$ ), además de incisos irregulares no registrados $(\mathrm{N}=5)$. De esto se infiere que la técnica incisa sería posterior al piqueteado, y su uso en intervenciones irregulares en paneles con o sin motivos definidos nos lleva a suponer la perduración de la práctica de inscribir las rocas, en la que la acción resultaría ser igual o más importante que el resultado. 


\section{Geoglifos}

Se trabajó en cinco sitios, todos ubicados en el límite poniente de la $\mathrm{CMCC}$, más o menos cercanos a la quebrada de Quipisca, sector conocido en la localidad como Alto Quipisca Sur y reconocido patrimonialmente por la CIQQ. En el marco de esta investigación se relevaron 11 motivos en cinco paneles (en este caso equivalentes a los sitios), cada uno de los cuales presenta una o dos figuras, salvo CO-03, que tiene cuatro (36,3\% del total) (Tabla 1). La clase representada de manera casi exclusiva es la geométrica ( $\mathrm{N}=10 ; 90,9 \%$ de la muestra), ya sean compuestos simétricos por reflexión ( $\mathrm{N}=2$ rectángulos/trapecios que se identifican con cruz o aves) o reflexión + traslación ( $\mathrm{N}=1$ rectángulos/trapecios que forman un rombo escalonado); geométricos compuestos no simétricos ( $\mathrm{N}=2$ círculo con apéndice; $\mathrm{N}=1$ líneas onduladas divergentes; y $\mathrm{N}=1$ rectángulos adyacentes más cruz simple, identificados en conjunto como campanario o torre de iglesia); o geométricos simples lineales ( $\mathrm{N}=1$ ángulo de 90; $\mathrm{N}=1$ irregular tipo bota) (Figura 6). Resulta excepcional en esta muestra un motivo zoomorfo tipo ave (aunque exhibe 4 patas), sobre el cual se ejecutaron dos círculos con apéndice y al cual se asocia también el campanario de iglesia de CO-03 (Figura 6A). En cuanto a las técnicas, los motivos fueron ejecutados principalmente por despeje, salvo las cruces o aves de CO-55_39, que combinan despeje y acumulación. Los motivos de CO-02 y CO-39 parecen ser complementarios, aunque también presentan diferencias en el grosor de los surcos.

Figura 6. Geoglifos: A) CO-03; B) CO-55; C) CO-02; D) CO-39; E) CO-55_39
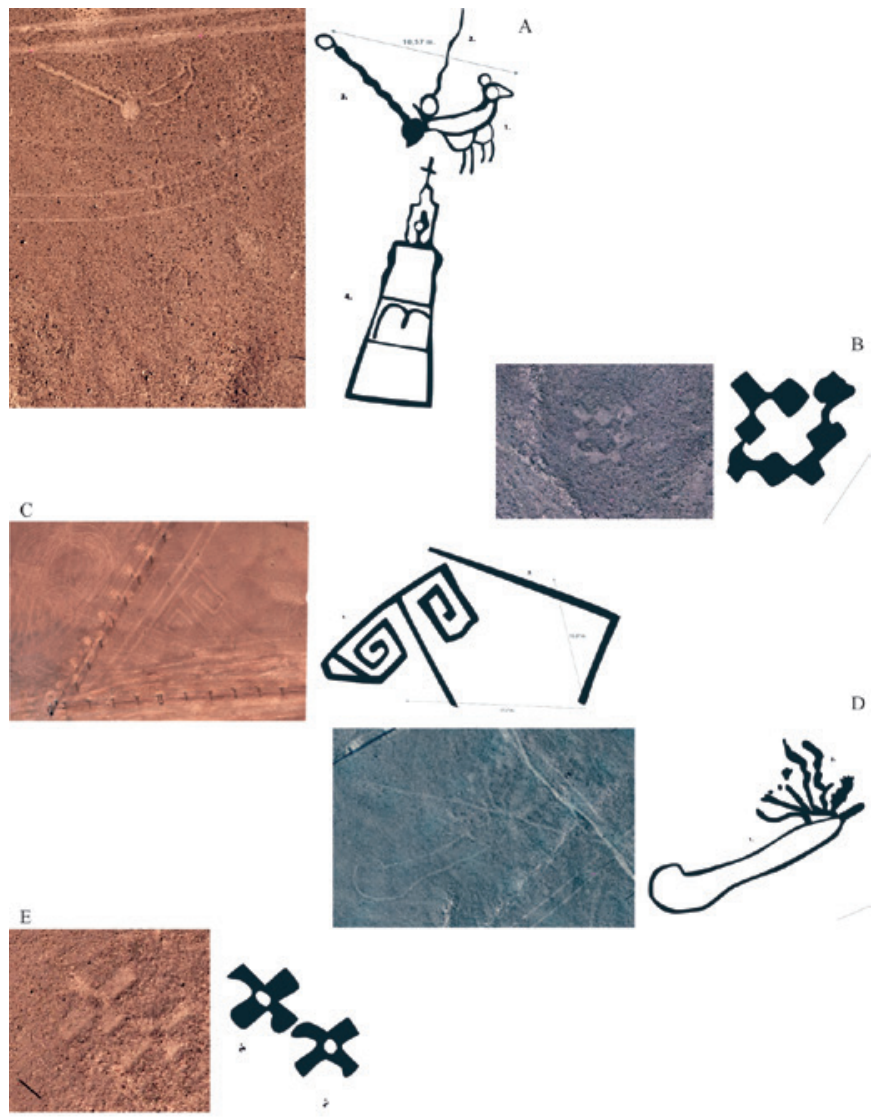

Elaboración propia, dibujos B. Brancoli. 


\section{Arte rupestre y vialidad}

Al evaluar la relación de los sitios de arte rupestre analizados con el sistema vial por fotointerpretación, se advierte que los caminos principales que recorren los márgenes de la mina Cerro Colorado poseen una baja visibilidad de los sitios con arte rupestre estudiado, ya que no se encuentran implantados sobre las formas más prominentes del paisaje como ocurre, por ejemplo, con otros geoglifos localizados en Cerro Negro (Figura 7). No obstante, sí se observan diferencias significativas entre las cuencas visuales generadas desde los mismos sitios con arte rupestre hacia los caminos.
Los sitios con petroglifos tienen un campo visual restringido, pero una buena visibilidad de los caminos, a los cuales están directamente asociados (Tabla 2). En específico Petroglifo 1, Petroglifo 2, Petroglifo 3 y Petroglifo 4 son visibles desde la ruta lquiuca-Mamiña, mientras CO-43 lo es desde el camino entre Quipisca y Mamiña (Figuras 7 y 8A). Por otra parte, los bloques rocosos que conforman dichos sitios poseen una buena visibilidad desde los mismos caminos, a pesar de que tienen tamaños relativamente pequeños. Los petroglifos de CO-14 y CO-37, al encontrarse más distantes de la ruta principal, que conduce a Mamiña-lquiuca o Mamiña-Quipisca, cuentan con menor visibilidad que la inferida para los bloques de los otros sitios.

Tabla 2. Proximidad de los caminos principales a los sitios de arte rupestre

\begin{tabular}{|c|c|c|c|}
\hline SITIO & TIPO & Caminos principales & Proximidad aprox. \\
\hline $\mathrm{CO}-02$ & Geoglifo & Quipisca-Mamiña & $20 \mathrm{~m}$ \\
\hline $\mathrm{CO}-03$ & Geoglifo & - & - \\
\hline $\mathrm{CO}-14$ & Petroglifos & $\begin{array}{l}\text { Mamiña-Iquiuca } \\
\text { Mamiña-Quipisca }\end{array}$ & $60 \mathrm{~m}$ \\
\hline $\mathrm{CO}-37$ & Petroglifos & $\begin{array}{l}\text { Mamiña-Iquiuca } \\
\text { Mamiña-Quipisca }\end{array}$ & $90 \mathrm{~m}$ \\
\hline CO-39 & Geoglifo & Quipisca-Mamiña & $12 \mathrm{~m}$ \\
\hline $\mathrm{CO}-43$ & Petroglifos & Mamiña-Quipisca & $0 \mathrm{~m}$ \\
\hline CO-55 & Geoglifo & Quipisca-Mamiña & $3 \mathrm{~m}$ \\
\hline Petroglifo 1 & Petroglifos & Iquiuca-Mamiña & $0 \mathrm{~m}$ \\
\hline Petroglifo 2 & Petroglifos & Iquiuca-Mamiña & $0 \mathrm{~m}$ \\
\hline Petroglifo 3 & Petroglifos & Iquiuca-Mamiña & $0 \mathrm{~m}$ \\
\hline Petroglifo 4 & Petroglifos & $\begin{array}{l}\text { Iquiuca-Mamiña } \\
\text { Mamiña-Quipisca }\end{array}$ & $0 \mathrm{~m}$ \\
\hline
\end{tabular}


Figura 7. Mapa de visibilidad entre caminos y paisaje o sitios con arte rupestre estudiados. Desde los caminos, solo tienen buena visibilidad las formas prominentes del paisaje (color salmón), primando una mala visibilidad circundante (celeste). Desde los sitios estudiados, se tiene buena visibilidad de ciertos segmentos de caminos (púrpura y rosa fuerte), aunque en su mayoría son poco visibles (amarillo).

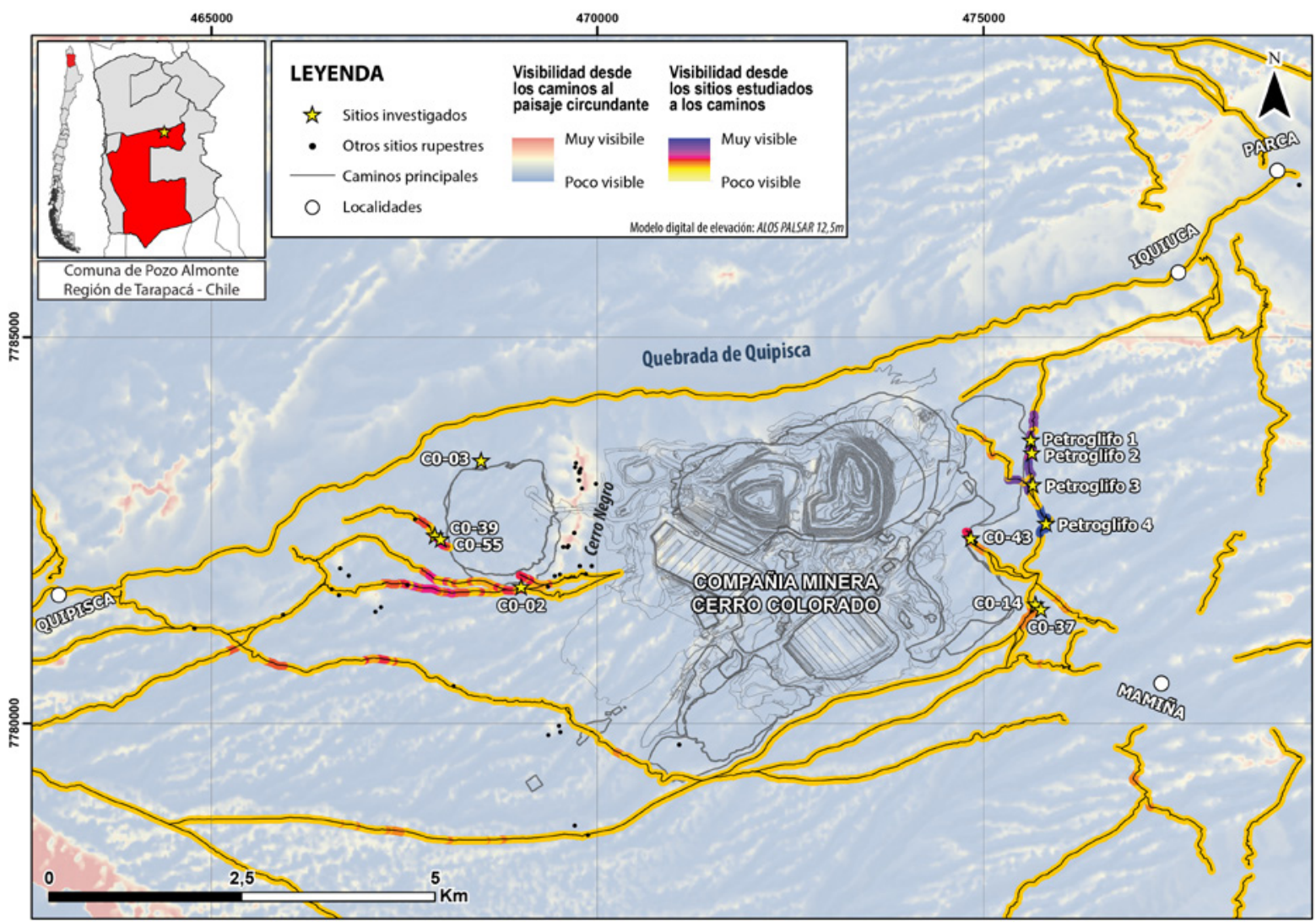

Elaboración propia con base en el modelo digital ALOS PALSAR. 
Figura 8. Arte rupestre, vialidad y paisajes. A) Petroglifo 2-B01-Pa; B) Geoglifo CO-55

A

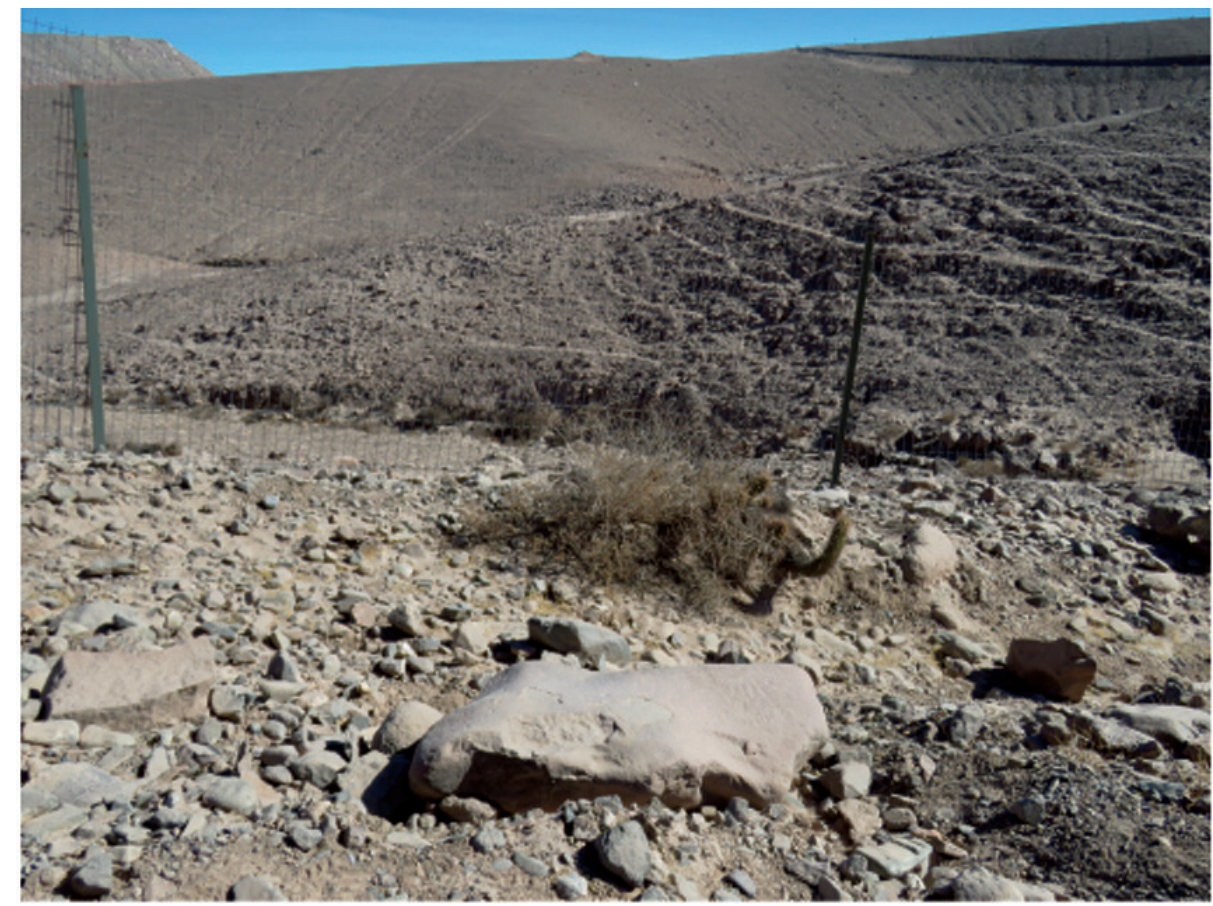

B

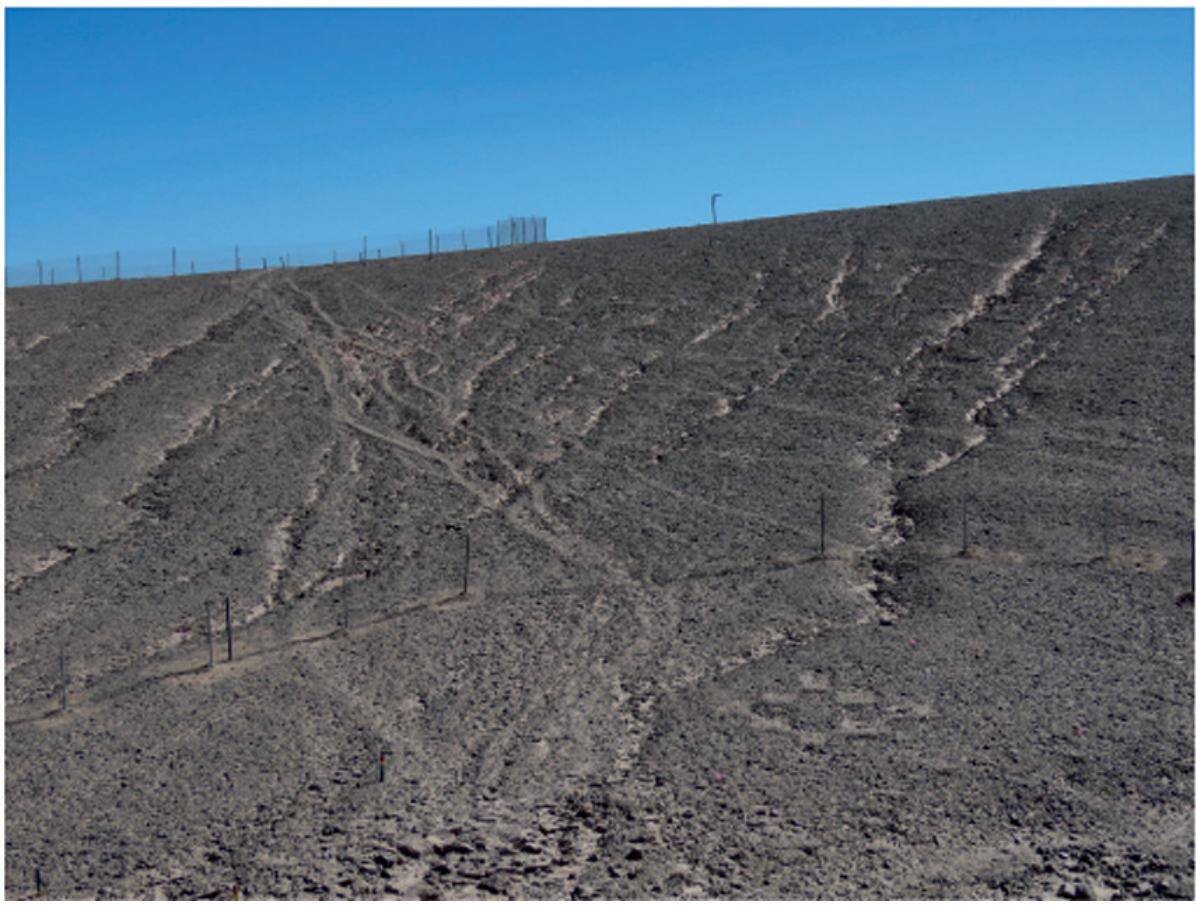

Fuente propia. 
Los sitios con geoglifos tienen un campo visual más amplio, pues desde ellos es posible observar al menos cuatro caminos que comunican exclusivamente con Quipisca y Mamiña, aunque la presencia de relieves irregulares provoca una segmentación de la superficie visible de dichos caminos (Figuras 7 y 8B). En particular, los paneles con geoglifos de CO-02, CO-39, CO-55 y CO-39_35 cuentan con una buena visibilidad desde los caminos principales, pero solo desde los más próximos y a una corta distancia debido a la escasa prominencia de sus emplazamientos y ángulos (Tabla 2). En este sentido, es posible que, por perspectiva, la mejor calidad paisajística del primer geoglifo es la que se consigue desde un sitio prominente desde el cual pueda ser observado desde lo alto (p. e., Cerro Negro), mientras que los demás se visualizan mejor desde la ladera opuesta. Distinto es el caso de CO-03, que no está asociado directamente a un camino principal y en el que la orientación de sus motivos pareciera indicar que fue creado para ser visto desde alguna vía emplazada en el margen norte de la quebrada de Parca (no identificada) o desde un lugar más prominente (p. e., Cerro Negro), sin descartar la posibilidad de que su importancia resida más en la acción de producirlo que en la de verlo (Figura 7).

\section{La vialidad más allá del arte}

El proceso de fotointerpretación dio cuenta de que los caminos vinculados a las manifestaciones rupestres están relacionados con una red mucho más amplia. Por una parte, se vinculan con 268 km de caminos principales que comunican las localidades del área de estudio con la quebrada de Tarapacá al norte, la quebrada de Macaya al sur y hacia el este con Noasa (Figura 9). Además, se vislumbra una vía hipotética orientada hacia el oeste desde Quipisca, la cual podría conectar dicho poblado con la pampa de Tamarugal y la costa. Por otra parte, se conectan, de forma complementaria, con caminos secundarios (388 km) y aislados $(111,7$ $\mathrm{km})$, agrupados mayoritariamente en torno a los poblados (en especial Mamiña), y que enlazan pequeñas quebradas y/o permiten el desplazamiento entre diferentes caminos principales. 
Figura 9. Mapa de la red vial de acuerdo con la tipología de caminos y los elementos asociados

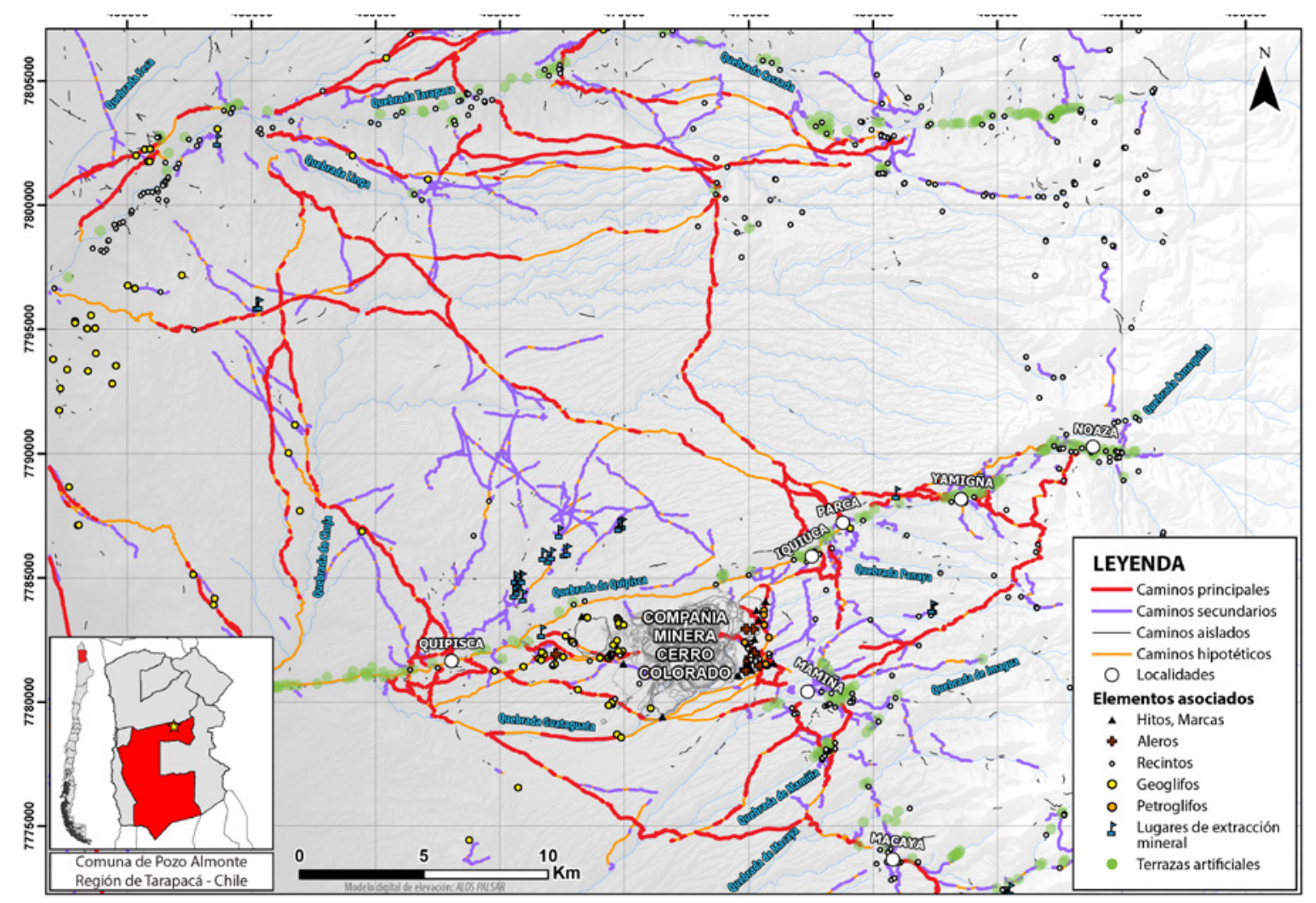

Elaboración propia con base en el modelo digital ALOS PALSAR.

Al incluir en esta red los registros previos vinculados a este proyecto (Yakuba, 2016) se observa que los sitios de petroglifos analizados $y$ los aleros se concentran en el margen este de la mina Cerro Colorado, junto a los caminos principales que comunican Mamiña con lquiuca y Parca (Figura 9). Hitos demarcatorios y otras marcas viales se distribuyen de manera preferente a lo largo de las vías que conducen desde Mamiña a Quipisca y desde Mamiña a lquiuca y Parca. Los geoglifos, en cambio, exhiben dos grandes concentraciones: una entre el margen oeste de la mina Cerro Colorado y el poblado de Quipisca; otra, al sureste del poblado de Tara- pacá, donde existen además otros geoglifos dispersos entre los caminos principales que se dirigen de Quipisca a Tarapacá. De este modo, si bien ambos conjuntos poseen elementos viales similares, los hitos y otras marcas visuales son más abundantes en el margen oriente, donde están los petroglifos, cuyo campo visual es más restringido. En el sector poniente se representan en menor cantidad, pues son los geoglifos los que tienen un campo visual más amplio.

De manera complementaria, por fotointerpretación se identificaron otros 672 elementos asociados a caminos: recintos $(50 \%)$, terrazas artificia- 
les (38\%), geoglifos (8\%) y lugares de extracción mineral (4\%), los cuales se distribuyen diferencialmente sobre el área total inspeccionada. Entre ellos destacamos los más cercanos a las localidades en estudio: agrupaciones de recintos (estructuras presumiblemente habitacionales) al sureste de Mamiña y entre esta localidad y los poblados de Parca e lquiuca; conjuntos de terrazas artificiales a lo largo de las quebradas de Parca (Quipisca, Iquiuca y Parca) y en torno a Mamiña; y lugares de extracción mineral que se concentran en especial al noreste del poblado de Quipisca (Figuras 9 y 10).

Figura 10. A) Recintos y terrazas de cultivo, quebrada de Quipisca, vista desde CO-03; B) Lugares de extracción mineral y senderos en la ladera, el Petroglifo 4 se halla en la base

A

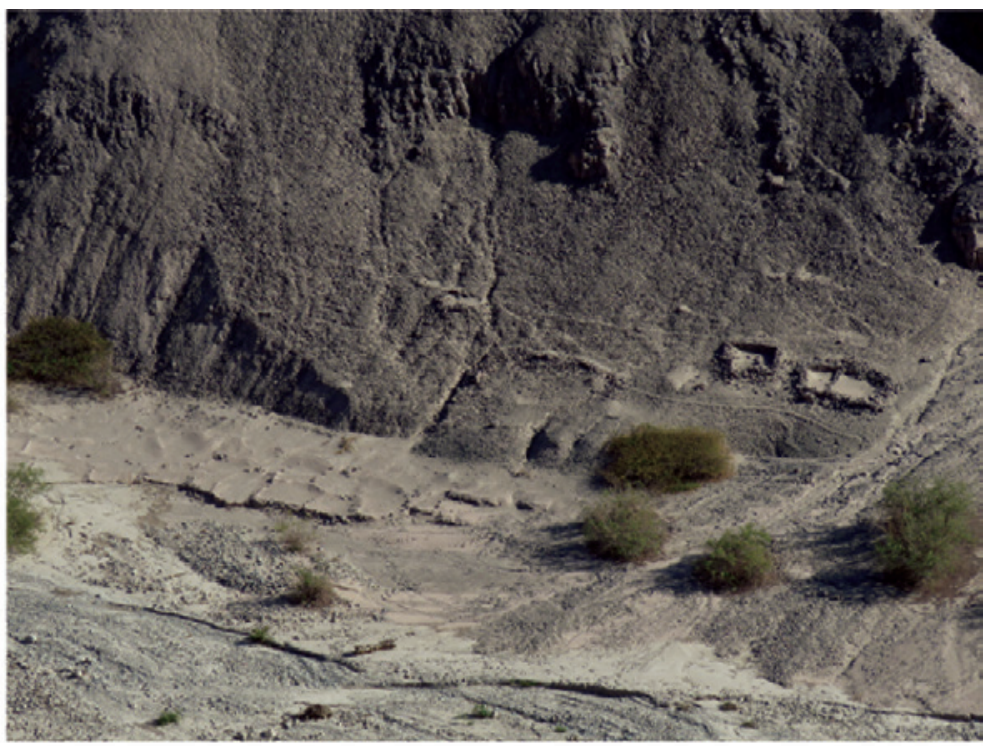

B

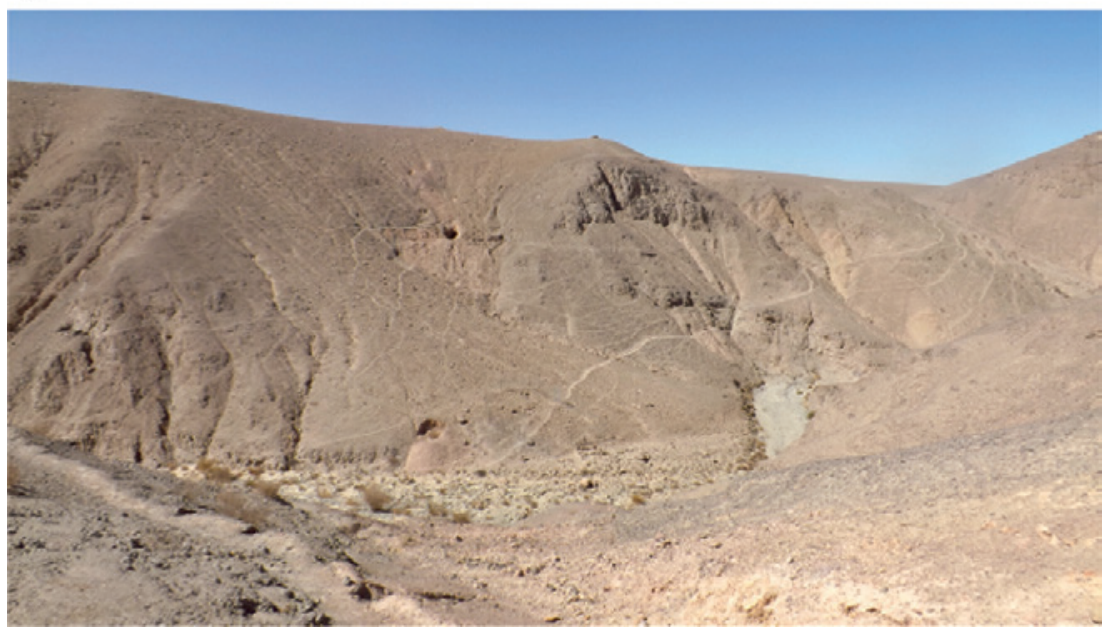

Fuente propia. 
La red vial a la luz de la historia y la etnografía

La red vial antes descrita halla sustento en la información histórica que da cuenta de caminos que conectan Quipisca y Mamiña con la quebrada de Tarapacá, y esta última con el altiplano boliviano (al salar y laguna de Coipasa, pasando por lquiuca y Parca, así como hacia el salar del Huasco vía Macaya). Este sector permitía también conectar a Mamiña, a través de Imagua y Sagasca, con espacios costeros ubicados al sur de lquique. En esa última vía se reconoce la existencia de un depósito de guano denominado Mamiña en las cercanías, hacia el noreste, de Punta Gruesa (Risopatrón, 1924, p. 520). El nombre del topónimo permite pensar en el uso de ese espacio por parte de los indígenas del poblado de Mamiña, quienes habrían compartido, con otros habitantes del interior, el uso y la explotación del guano, en lo cual es posible percibir una continuidad de usos y circulaciones antiguas.

También se detecta un enrejillado ${ }^{9}$ de caminos existentes entre las quebradas de Quipisca, Mamiña, lquiuca y Parca hacia sectores de cultivo compartidos o campamentos mineros (Niemeyer, 1961; Larraín, 2012; CONADI, 2013; Olmos et al., 2018). En efecto, desde sus inicios, la administración hispana se concentró en los pueblos de Tarapacá, Pica, Matilla, Guatacondo, Camiña, Sibaya e lquique, y en los minerales de Guatanjaya y Chanabaya. En estos espacios se desarrollaban actividades económicas rentables y se controlaba la producción especializada (de oasis, costa, altiplano) y su inserción en circuitos de comercialización dentro y fuera del espacio tarapaqueño, hacia, por ejemplo, Potosí, lo que permite pensar en un manejo colonial del área desde rutas preexistentes (Bermúdez, 1963; Larraín, 1975; Villalobos, 1979; Advis, 1990; Odone, 1994; Hidalgo, 2009). Las pobla- ciones indígenas eran las encargadas del traslado de productos y mercancías a través de vías troperas previas (Alcedo \& Herrera, 1967 [1786-1789]; Van Kessel, 1980; Hidalgo, 2004).

A partir de la segunda mitad del siglo XIX, los poblados de Quipisca y Mamiña aumentaron sus producciones agrícolas, ganaderas, forrajeras, de carne, carbón y leña, las cuales eran trasladadas y distribuidas en recuas de mulas y burros para abastecer las oficinas salitreras hasta por lo menos las primeras décadas del siglo XX. Esto desarrolló un comercio de ida y vuelta, puesto que los viajeros regresaban con productos como aceite, harina, azúcar, té o yerba mate (Boletín de la Guerra del Pacífico, 1979 [1879-1881]; Hernández, 1930; Bermúdez, 1963; Cobo, 1971; Albornoz \& Mac Phee, 2008; Urrutia, 2011; Larraín, 2012; CONADI, 2013; Odone, 2018).

La existencia de estas redes se ve refrendada en los testimonios entregados en las distintas instancias de trabajo etnográfico realizadas con la CIQQ, la CIQM, la CIQI, la AIAKK y la AIACQ (Tabla 3). En ellos se reconoce, en forma colectiva, una percepción integral del territorio, construido por áreas de cultivo, de pirquinería histórica y de ganadería, caminos troperos, senderos, sectores de descanso caravanero, sitios arqueológicos, etc., que se hallan en las quebradas aledañas y en los distintos pisos ecológicos de la región (Figuras 11-14). Con más precisión, las comunidades y asociaciones indígenas reconocen que las vías de circulación analizadas en el marco de esta investigación (caminos, senderos, hitos demarcatorios y otras marcas viales) conectaron en ambas direcciones Iquiuca-Mamiña y Quipisca-Mamiña. Adicionalmente, los relatos destacan los caminos alrededor de la quebrada de Tarapacá, la quebrada de Macaya, Noasa y hacia la pampa del Tamarugal y la costa. Respecto de los sitios 
en estudio, aquellos ubicados al oriente de lo que fuera el Cerro Colorado son identificados por la CIQI, la CIQM y la AIAKK, aunque no se asocian directamente al sistema vial, como ocurre con apachetas y sitios habitacionales cercanos a las localidades y en los cerros ceremoniales circundantes (como Jamajuga y Cerro Inka, que actualmente son utilizados para realizar rituales).

También se considera que geoglifos y petroglifos se realizaban con el objetivo de transmitir mensajes asociados a la naturaleza y la interacción con el hombre. En cuanto a los geoglifos que se hallan en el margen oeste del antiguo cerro, junto con otros sitios arqueológicos en torno a Quipisca y hacia la quebrada de Tarapacá (vid. supra), estos son señalados por la CIQQ como distintos even- tos que complementan y articulan la red vial. Ello da cuenta de una ocupación continúa del territorio.

Por su parte, la AIACQ también comprende estos eventos arqueológicos como hitos demarcatorios relacionados con los caminos troperos que conectaron las distintas zonas de este piso ecológico, aunque reconocen un desconocimiento sobre su significado a causa del quiebre generacional que significó el fallecimiento de quienes circularon por estas rutas. Las diferencias en la comprensión integral de los contextos arqueológicos responderían, por una parte, a la desvinculación con el territorio generada tras la migración a la ciudad de lquique desde la década de 1960 y, por otra, al tiempo que las distintas entidades llevan explorando el tema patrimonial con asesores especializados.

Tabla 3. Instancias de trabajo etnográfico realizadas con cada organización indígena vinculada a la investigación

\begin{tabular}{|c|c|c|}
\hline Organización & $N^{\circ}$ actividades & Tipo de actividades \\
\hline $\begin{array}{l}\text { 1. Comunidad Indígena Quechua } \\
\text { de Quipisca }\end{array}$ & 16 actividades & $\begin{array}{l}\text {-Reuniones con Directiva } \\
\text {-Focus group } \\
\text {-Entrevistas individuales } \\
\text {-Salida a terreno (visita a sitios arqueológicos) }\end{array}$ \\
\hline $\begin{array}{l}\text { 2. Comunidad Indígena Quechua } \\
\text { de Iquiuca }\end{array}$ & 14 actividades & $\begin{array}{l}\text {-Reuniones con Directiva } \\
\text {-Focus group } \\
\text {-Entrevistas individuales } \\
\text { - Salida a terreno (visita a sitios arqueológicos) }\end{array}$ \\
\hline $\begin{array}{l}\text { 3. Comunidad Indígena Quechua } \\
\text { de Mamiña }\end{array}$ & 16 actividades & $\begin{array}{l}\text {-Reuniones con Directiva } \\
\text {-Focus group } \\
\text {-Entrevistas individuales }\end{array}$ \\
\hline $\begin{array}{l}\text { 4. Asociación Indígena Aymara } \\
\text { Kespi Kala de Mamiña }\end{array}$ & 11 actividades & $\begin{array}{l}\text {-Reuniones con Directiva } \\
\text {-Entrevistas individuales } \\
\text { - Salida a terreno (visita a sitios arqueológicos) }\end{array}$ \\
\hline $\begin{array}{l}\text { 5. Asociación Indígena Aymara } \\
\text { Cuenca de Quipisca }\end{array}$ & 7 actividades & $\begin{array}{l}\text {-Reuniones con Directiva } \\
\text {-Focus group }\end{array}$ \\
\hline
\end{tabular}


Figura 11. Mapa con rutas troperas y lugares de significancia patrimonial de la Comunidad Indígena Quechua de Quipisca (CIQQ)

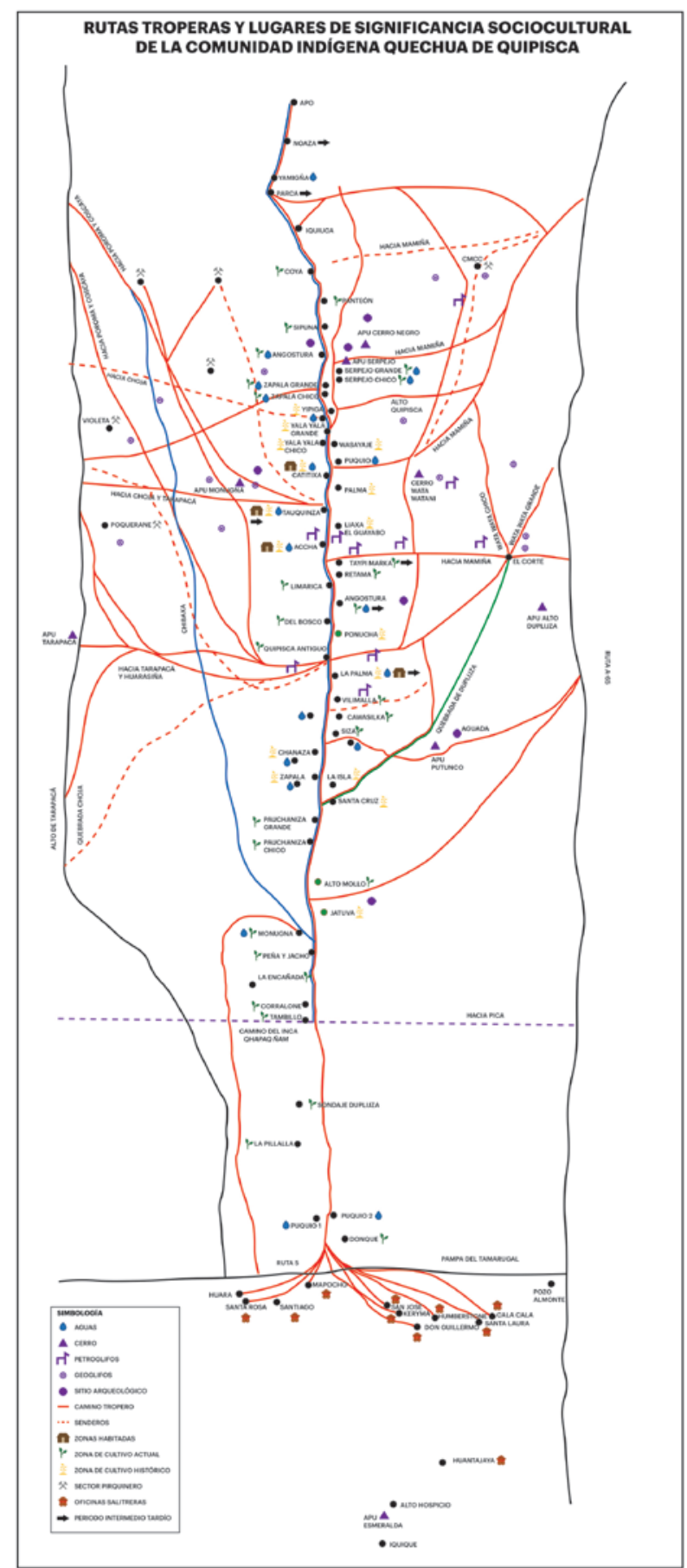

Elaboración propia mediante cartografías participativas con la comunidad. 
Figura 12. Mapa con rutas troperas y lugares de significancia patrimonial de la Comunidad Indígena Quechua de Mamiña (CIQM)

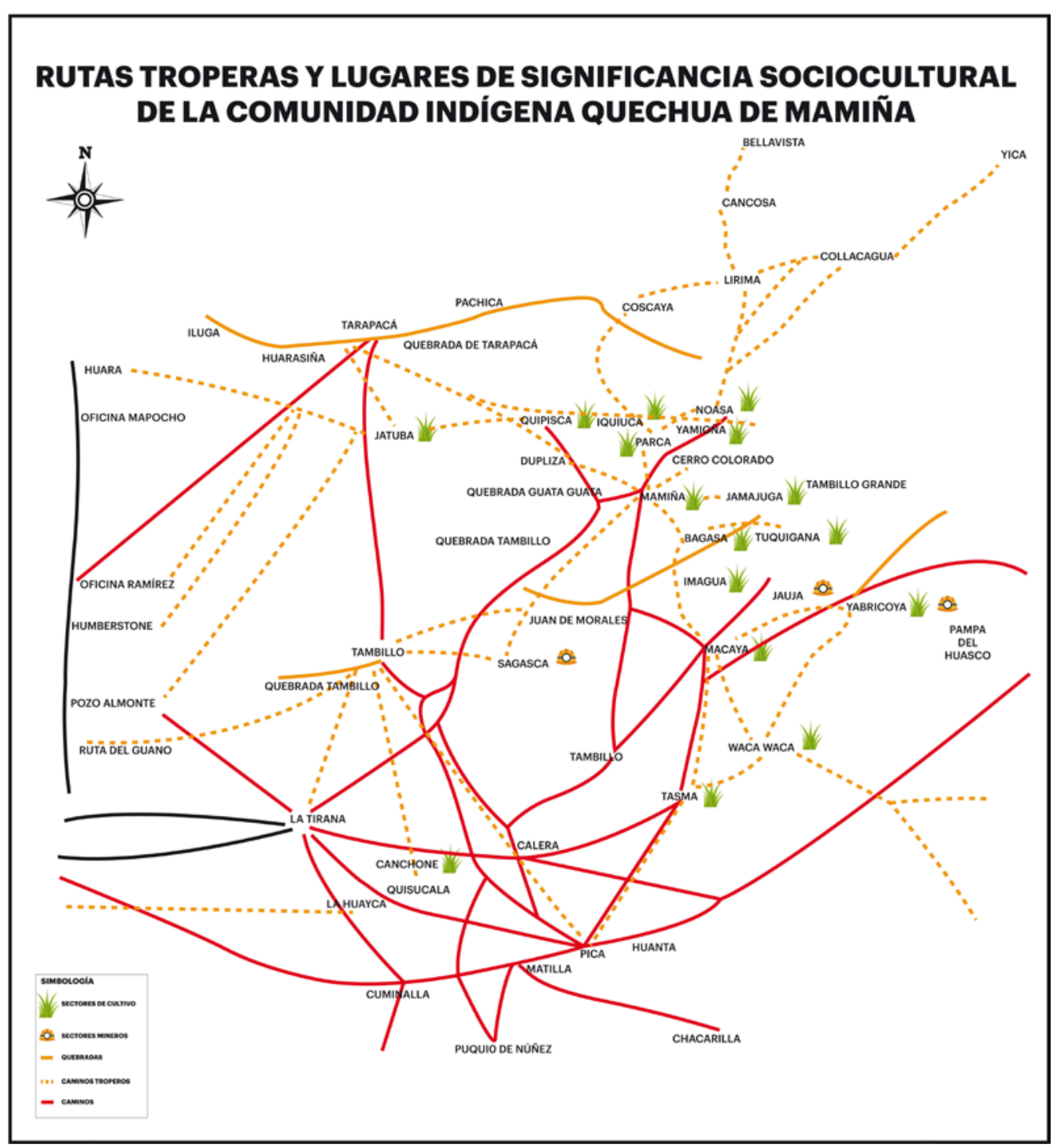

Elaboración propia mediante cartografías participativas con la comunidad. 
Figura 13. Mapa con rutas troperas y lugares de significancia patrimonial de la Comunidad Indígena Quechua de Iquiuca (CIQI)

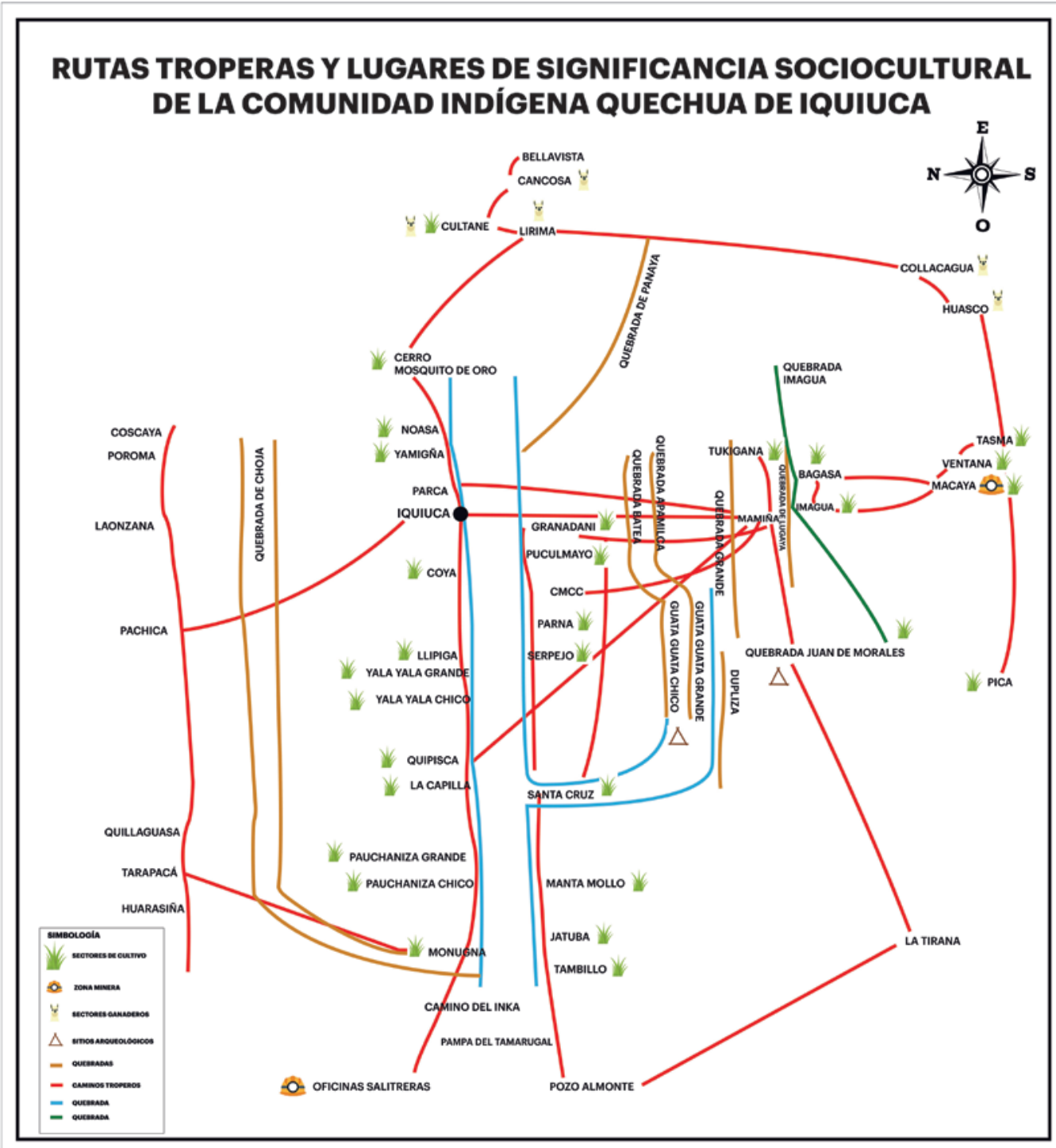

Elaboración propia mediante cartografías participativas con la comunidad) 
Figura 14. Mapa con rutas troperas y lugares de significancia patrimonial de la Asociación Indígena Aymara Kespi Kala de Mamiña (AIAKK)

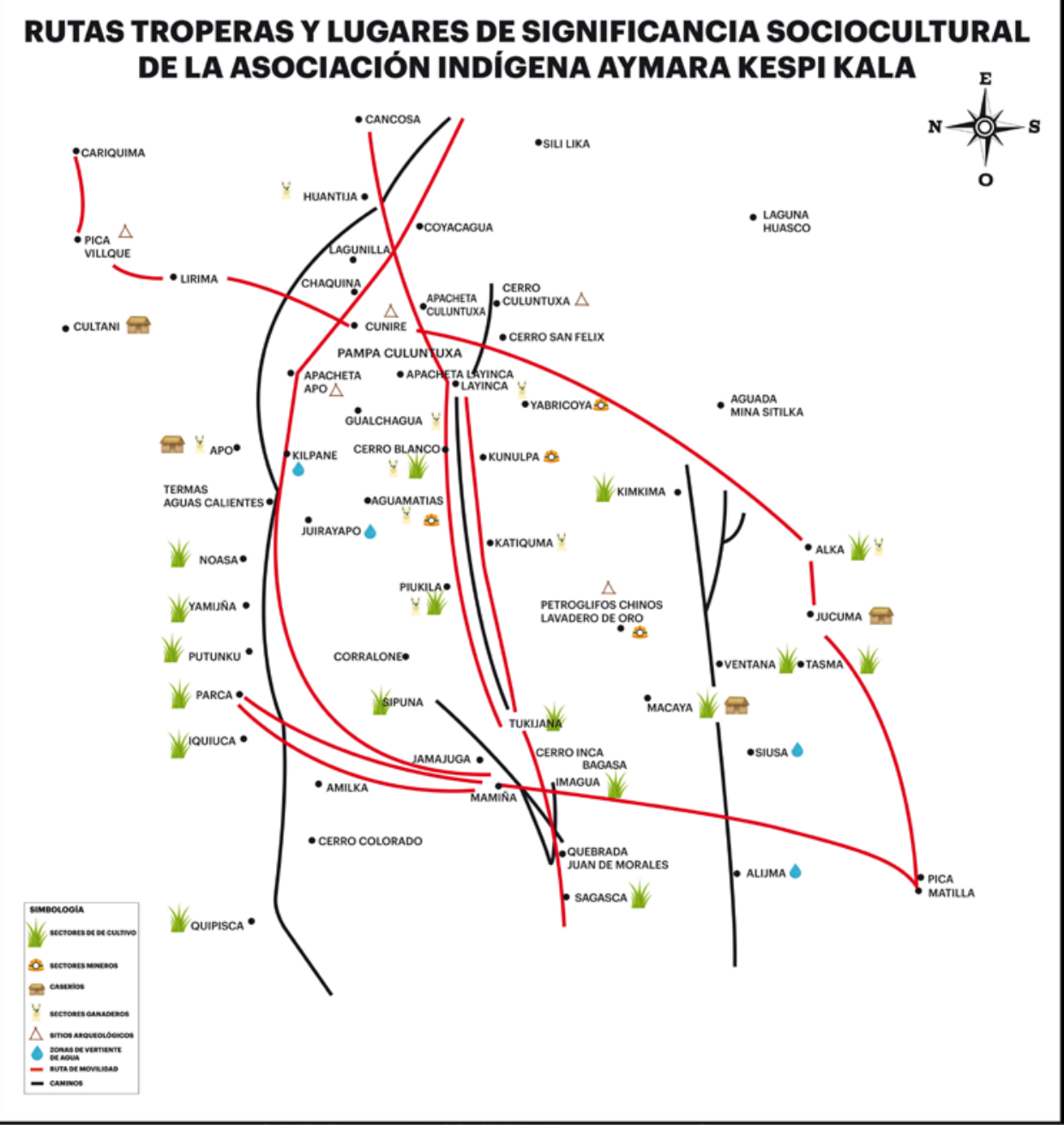

Elaboración propia mediante cartografías participativas con la asociación.

En la memoria social de las comunidades y las asociaciones indígenas, las redes viales se distinguen de acuerdo con la finalidad de tránsito, basada en tres objetivos fundamentales. En primer lugar, el desarrollo agrícola para la subsistencia familiar, vinculado a los caminos que conectan las localidades con sectores de cultivo.
En segundo lugar, se reconoce que permitieron viabilizar las dinámicas comerciales entre distintas localidades y/o pisos ecológicos, mediante intercambio y/o comercialización a pequeña escala de productos mayormente agrícolas destinados al consumo familiar. Todo esto se realizaba a través de caminos troperos con dirección 
noroeste hacia las oficinas salitreras, caminos con rumbo este hacia el altiplano y rutas con orientación norte-sur que conectaron con las localidades de la quebrada de Tarapacá, La Tirana y Pica. Finalmente, las distintas vías de comunicación contribuyeron a establecer relaciones interpersonales y facilitar la participación colectiva en festividades de la tradición religiosa andina o familiares (como entierros o curaciones medicinales), a las cuales convergían múltiples lugareños.

En la actualidad, el desarrollo agrícola involucra nuevas dinámicas para su producción, comercialización y traslado, que incluyen el uso de vehículos motorizados que circulan por vías pavimentadas o estabilizadas y cuyo recorrido es distinto -aunque en algunos segmentos se superpone- a los antiguos senderos y caminos troperos. Por esta razón, hoy en día, el uso de estos últimos se circunscribe a circunstancias específicas, como crecidas de río, cortes de caminos vehiculares, entre otras.

Finalmente, cabe destacar que las comunidades y asociaciones indígenas le otorgan especial atención a los sitios arqueológicos en tanto hitos que articulan un pasado histórico de ocupación territorial y que, al día de hoy, son una pieza fundamental para fortalecer la construcción de su identidad cultural y el desarrollo estratégico de resignificación de su patrimonio material.

\section{Arte rupestre y vialidad a través del tiempo, una secuencia desde la arqueología, la historia y la etnografía}

Para los tiempos prehispánicos, podemos sugerir una cronología relativa al uso de las rutas en estudio a partir de los cambios en la producción del arte rupestre asociado a ellas.
Si bien nuestro registro se limitó a determinados sitios de las rutas en torno a Cerro Colorado y no al universo completo, no se reconocieron en este caso "iconos claves" u otros elementos vinculables al período formativo que sí están presentes en otros segmentos viales de la región, como Tamentica-1, Ariquilda 1, Chusmisa y Cerro Unita (Meighan, 1980; Chacama \& Espinosa, 1997; Vilches y Cabello, 2011; Cabello \& Gallardo, 2014). Su ausencia aquí permite postular que las rutas en torno al Cerro Colorado no fueron utilizadas activamente antes del primer milenio después de Cristo. Esta suposición resulta consistente con la ocupación de lugares altos y propicios para la agricultura registrada entre las quebradas de Camiña y Mamiña a partir del año 1200 d.C. (Urbina \& Adán, 2006; Uribe, 2006; Uribe et al., 2007).

En efecto, la mayor parte de los motivos reconocidos en este estudio participan del repertorio visual presente en contextos habitacionales y de tránsito del PIT (Núñez, 1965b; Núñez \& Briones, 1967-1968; Gallardo, 1996; Chacama, 2003; Sepúlveda, Romero \& Briones, 2005; Vilches \& Cabello, 2011). Si bien la muestra analizada de geoglifos es pequeña, aves, círculos con apéndices y en especial el "rombo de lados escalerados" o "escalonado" coinciden con las figuras más representadas en los geoglifos y petroglifos de Tarapacá desde los valles interiores a la costa (Núñez \& Briones, 1967-1968; Núñez, 1976). Menos comunes entre los geoglifos asociados a rutas sería el ejemplar definido como "Dos volutas unidas por un eje central" y los dos "Rectángulos y trapecios en reflexión (cruz de lados iguales o ave)" (Cerda et al., 1985; Chacama \& Briones, 1996), aunque el último motivo se registra también en un grabado del sitio habitacional Jamajuga, cercano a Mamiña (Vilches \& Cabello, 2011). 
Otra gran variedad de motivos y temas descritos para los sitios con arte rupestre de este período fue reconocida en los petroglifos analizados (Núñez, 1965b; Núñez \& Briones, 19671968; Vilches \& Cabello, 2011): líneas, grecas, camélidos, lagartos, antropomorfos con vestimenta, parejas en movimiento, unidos por las manos a otros o a animales en caravana, entre muchos. La similitud en la frecuencia de los tipos representados (donde priman los geométricos por sobre antropomorfos y zoomorfos), junto a la unidad en las técnicas de producción de estos motivos, refuerzan la idea de un estilo común que vincula las localidades en torno al Cerro Colorado con los procesos sociales y económicos regionales acaecidos durante el PIT.

De esta forma, estas rutas habrían servido no solo a la circulación de personas, bienes y productos, sino también de información visual, la cual, plasmada a través de signos reconocibles, permitió construir un paisaje común para quienes circulaban por ellas, tal y como se ha propuesto para los geoglifos y otras manifestaciones rupestres de áreas vecinas (Gallardo et al., 2012; Gallardo et al., 2018). La ausencia de representaciones marinas (peces, balsas, etc.) podría deberse a que estas vías, con orientación nortesur, conectaron principalmente las localidades entre quebradas y no directamente con la costa, por lo que no tenían la necesidad de expresar elementos identitarios costeros, como ocurre en los sitios habitacionales (Vilches \& Cabello, 2011). Esta carencia también podría explicarse por diferencias cronológicas, ya que la producción del arte rupestre en estudio podría haber ocurrido durante la fase Camiña (1200-1430 d.C.), vinculada con el énfasis que adquieren en esta época las poblaciones de las quebradas y el altiplano tarapaqueño debido al desarrollo agrícola. Las manifestaciones en torno a la pampa del Tamarugal, en cambio, podrían haberse realizado principalmente durante la fase Tarapacá (890-1250 a.C.) o antes, cuando el hincapié productivo estaba enfocado en los recursos forestales de los sectores bajos de los valles y en la costa (Uribe, 2006; Uribe et al., 2007).

Si bien es difícil discernir entre los motivos antropomorfos con vestimenta del PIT y el PT (Gallardo, 2018), reconocemos al menos cuatro ejemplares propios de este último: el unku, con decoración en $\mathrm{X}$; el personaje que porta hachas; aquel con cabeza cortada; y el que posee un "emplumado" en su espalda. Aunque estos cuentan con referentes previos allende los Andes (Lorandi, 1966; Nielsen, 2007; Callegari, Wisnieski, Spengler, Rodríguez \& Aumont, 2009), su presencia en nuestro territorio ha sido interpretada como consecuencia de la promoción de ciertos objetos y prácticas distintivas de la identidad étnica por parte del Tawantinsuyu (Bibar, 1966; Troncoso, 2011; Berenguer, 2013; López Campeny \& Martel, 2014; Gallardo, 2018). Lo mismo ocurre con los camélidos rectilíneos -como algunos registrados en este estudio-, que han sido interpretados como resultado de la extensión por toda el área circumpuneña, y en distintos soportes, del "diseño iconográfico oficial" que este animal adquiere en tiempos incaicos (Gallardo \& Vilches, 1995, 2001; Vilches, 1999; Aschero, 2000; Sepúlveda, 2004). En la elaboración de estos motivos no se observan diferencias técnicas con el grupo antes descrito, de modo que se trataría principalmente de la incorporación de nuevos elementos al imaginario visual de los habitantes de las quebradas interiores de Tarapacá.

No mucho más tarde (1500 d.C.), la conquista y colonización española generaría profundos cambios en la población nativa de Tarapacá a partir de la inserción de los espacios indíge- 
nas de Quipisca, Mamiña, Iquiuca y Parca en la organización político-administrativa hispana y su inclusión en el sistema de encomiendas de Tarapacá/Pica/Loa entre los siglos XVI y XVIII (Larraín, 1975; Villalobos, 1979; Odone, 1994). Desde entonces y hasta la segunda mitad del siglo XVIII, las poblaciones indígenas fueron las encargadas del traslado de los productos y las mercancías que se generaban en distintos espacios tarapaqueños, para lo cual utilizaban prácticamente las mismas rutas. Para este contexto histórico temprano se reconoce una continuidad en la producción rupestre, que incorpora, reconfigura y resignifica la iconografía occidental en geoglifos, pinturas y, sobre todo, petroglifos de distintas partes de Tarapacá y del área andina, al mismo tiempo que motivos rupestres de raigambre prehispánica son pintados en los muros de las iglesias (Martínez, 2009; González, 2014; Arenas \& Odone, 2016; Gallardo, 2018).

En nuestra muestra, la época histórica estaría representada en los grabados de CO-43, cuyas "cruces de malta", así como letras y números cuya grafía podría corresponder a marcas de ganado vinculadas a prácticas arrieras de fines del siglo XIX e inicio del XX, dan cuenta de una continuidad en la circulación de las rutas por parte del componente indígena, al igual como se ha documentado más allá de los Andes (Podestá, Rolandi, Re, Falchi \& Damiani, 2006). También se reconoce en uno de los geoglifos de CO-03 definido como "Rectángulos adyacentes y cruz", que corresponde a un campanario o torre de iglesia. En efecto, la cruz, representada de forma individual o asociada a calvarios, campanarios o torres de iglesia, es uno de los significantes más evidentes en la incorporación de iconos cristianos a las lógicas representacionales indígenas (Odone, 1994). Sin embargo, la presencia de similares representaciones en Dupliza/Mamiña (Núñez \& Briones, 1967-1968) podría responder también a lógicas hispanas demarcatorias de espacios que integraban administraciones eclesiásticas ${ }^{10}$, en este caso de la parroquia del pueblo de San Marcos de Mamiña, que también tenía como patrona a la Virgen del Rosario (Odone, 1994).

Otro ejemplo de la perduración de esta práctica en nuestra muestra sería la utilización de incisos para complementar o destacar rasgos en figuras previamente ejecutadas, como intervenciones irregulares junto a motivos definidos, o bien su factura en soportes de forma exclusiva en los sitios con más petroglifos. Esto nos lleva a suponer que la acción de inscribir las rocas resultaría igual o más importante que el resultado. La identificación de esta técnica para realizar motivos de data colonial, junto o sobre ellos, en otros sectores del desierto de Atacama (Gallardo et al., 1990) apoya esta idea, pese a que su ubicación en la secuencia temporal resulte compleja.

Los registros históricos y etnohistóricos y las memorias sociales que poseen las comunidades y las asociaciones indígenas informan que las vías y los caminos troperos que unían las quebradas de Quipisca, Mamiña, Iquiuca y Parca con la pampa del Tamarugal, la costa, la quebrada de Tarapacá, el altiplano boliviano y los oasis de Pica y Matilla siguieron utilizándose de forma activa hasta tiempos subactuales. A partir de la segunda mitad del siglo XIX los poblados de Quipisca y Mamiña fueron centrales en suministrar recursos y productos a oficinas y pueblos salitreros de los cantones de Pozo Almonte, La Noria, Alto San Antonio y Huara (González, 1989; González \& Artaza, 2013; Olmos et al., 2018). 
A su vez, junto con esta circulación a gran escala, que se configura por razones económicas, coexiste una movilidad y un tránsito de personas asociados a la vida y las necesidades locales y familiares, como el acceso a zonas de cultivo, la continuidad de las redes de relaciones interpersonales y la participación colectiva en festividades de tradición andina, religiosas o familiares. En este contexto, resulta importante destacar las valoraciones sociales y simbólicas que poseen las comunidades y las asociaciones indígenas sobre las vías de comunicación en determinados sectores geográficos y cerros ceremoniales. Estas rutas, junto con los registros arqueológicos de diverso orden (petroglifos, geoglifos, estructuras habitacionales, aleros, caminos troperos, corrales, entre otros), son entendidas no como eventos inconexos, sino propios del paisaje sociocultural e histórico.

\section{Conclusiones}

Los análisis del arte rupestre en esta zona dan cuenta de que las vías principales Quipisca-Mamiña-Macaya y Mamiña-Iquiuca-Parca fueron utilizadas activamente desde el PIT, durante la incorporación al Tawantinsuyu y en la Colonia. Si bien la producción rupestre no se constata para períodos posteriores, el uso de estas rutas continuó hasta épocas recientes, al igual que el de los caminos secundarios y senderos interiores, al enlazar quebradas cercanas y vincular espacios asociados a la actividad agrícola, ganadera y minera. Los caminos, a su vez, permitieron el acceso al curso superior de la quebrada de Tarapacá, a espacios del actual altiplano boliviano, a la pampa del Tamarugal, a los oasis de Pica y Matilla y a la costa tarapaqueña. A través de ellos, distintos grupos indígenas interactuaron y complementaron los bienes y recursos de distin- tos nichos ecológicos, logrando con ello responder a las exigencias de las economías propias de cada período. A su vez, mantuvieron ese paisaje vial en cuanto columna vertebral que permitió articular relaciones sociales, culturales, simbólicas y rituales centrales para la vida histórica de sus localidades.

Frente a las adversidades que representan las largas travesías por espacios del desierto tarapaqueño, el arte rupestre se reconoce como una respuesta de continuidad o permanencia justamente de relaciones sociales, económicas y rituales entre espacios locales y otros más distantes. A través del tiempo, los motivos comunes a la sociedad tarapaqueña fueron reemplazados por iconos occidentales y luego por incisiones irregulares cuya acción resultaría igualmente significativa en el tránsito por estas vías. Ello permite proponer que esos nuevos códigos visuales se integraron a un imaginario preexistente, ampliándolo con nuevas significaciones y dotando al arte rupestre de una vida activa en el actual contexto histórico de las localidades de Quipisca-Mamiña-Macaya y Mamiña-Iquiuca-Parca.

Los resultados aquí presentados dan relevancia a un área donde se concentraron importantes rutas con orientaciones diversas y cuyo uso fue gravitante en el tiempo, desde al menos el PIT. La historia de los núcleos poblacionales de la región si bien es importante y ha sido ampliamente destacada en las investigaciones arqueológicas e históricas (Urbina \& Adán, 2006; Uribe, 2006; Santoro et al., 2017), no fue posible sin la configuración del espacio que existe entre ellos y por donde no solo circularon personas y recursos, sino ideas e información relevantes para la vida en el desierto, algunas de las cuales se plasmaron 
en imágenes que modifican el paisaje (Nielsen, 2006; Berenguer \& Pimentel, 2017) y cuyo uso sigue siendo muy relevante.

El arte rupestre es entendido por las comunidades y asociaciones indígenas como un registro más relacionado con las rutas y el paisaje social. Es justamente en torno a las estrategias de apropiación y uso territorial que estas organizaciones han generado dinámicas compartidas y redes de colaboración pensadas para la protección y la puesta en valor del patrimonio arqueológico e histórico de los sectores de significación cultural. En este contexto, esperamos aportar desde la arqueología, la historia y la etnografía, al re/conocimiento y la re/integración de Cerro Colorado como paisaje cultural. En consonancia con estos objetivos, con el trabajo interdisciplinario y la utilización de variadas e inéditas metodologías de trabajo, pretendemos también abrir nuevas perspectivas y desafíos para futuras investigaciones.

\section{Notas}

\footnotetext{
${ }^{1}$ Trabajo realizado como parte de las Medidas de Compensación General de Difusión y Educación Patrimonial de acuerdo a los términos establecidos en el Proyecto Continuidad Operacional Cerro Colorado (RCA N 0069/2015) y en los Protocolos de Acuerdo Final (PAF) con la Comunidad Indígena Quechua de Mamiña, la Asociación Indígena Aymara Kespi Kala de Mamiña, la Comunidad Indígena Quechua de Quipisca, la Asociación Indígena Cuenca de Quipisca, la Comunidad Indígena Quechua de lquiuca y la Comunidad Indígena Aymara de Parca. Esta última comunidad decidió finalmente no participar en la investigación.

2 En estas manifestaciones visuales distinguimos los petroglifos, diseños incisos o grabados en bloques rocosos o paredes de quebradas, de amplia distribución en el país; y los geoglifos, figuras realizadas mediante la acumulación y/o despeje de la superficie natural del suelo, ya sea en laderas de los cerros o en sectores planos hallados principalmente en el norte del país (Mostny \& Niemeyer, 1983).

${ }^{3}$ Las apachetas corresponden a un gran montículo de piedras
}

\section{Agradecimientos}

A la Comunidad Indígena Quechua de Quipisca, la Comunidad Indígena Quechua de lquiuca, la Comunidad Indígena Quechua de Mamiña, la Asociación Indígena Aymara Kespi Kala y la Asociación Indígena Aymara Cuenca de Quipisca por la confianza y la generosidad concedida al equipo de investigación. A Bernardita Brancoli y sus dibujantes; a Alex Paredes y su equipo de topografía; a Carole Sinclaire, Diego Artigas, Consuelo Carracedo y Francisca Fernández, participantes del registro arqueológico. A Josefina Domeyko y Daniela Uribe, ayudantes de la investigación etnohistórica y a Gabriel Ruy-Pérez, ayudante de la investigación etnográfica. A Maricel Beltrán, Nicolás Riquelme y Raúl García por sus gestiones. A Diego Salazar por sus valiosos comentarios para mejorar el manuscrito. Al proyecto FONDAP 15110006. Este trabajo fue posible gracias a la Compañía Minera Cerro Colorado (CMCC). La coordinación técnica estuvo a cargo de Golder Associates.

de forma piramidal construido colectivamente a través del tiempo, junto a la realización de ofrendas y de la solicitud de protección a las huacas, para marcar la ruta y el paisaje (Pimentel, 2009, p. 11). Esta práctica fue significativa para quienes usaban las rutas desde el pasado prehispánico hasta tiempos muy recientes (Galdames, 1990). Son un icono de la infraestructura vial andina.

${ }^{4}$ Muestra de músculo humano datada en $3110+40$ a.p. (Beta50707), calibrada en 3370-3320 a.C. (Briones et al., 2005, p. 213).

${ }^{5}$ Fechas C-14 AMS calibradas en 1020-1370 d.C. (Beta-90198) para Challacollito y 1165-1396 (Beta-84411 y Beta-86314) para quebrada Los Pintados (Clarkson, Rivera \& Dorn, 2001).

${ }^{6}$ En el área de influencia de la CMCC hay registro de 164 sitios arqueológicos: 42 geoglifos, 40 tramos viales, 26 hitos/marcas viales, 22 sectores con recintos, 13 aleros, 9 conjuntos de petroglifos y 12 de otros tipos. De ellos, solo ocho sitios habitaciones fueron adscritos al PIT y uno a tiempos históricos recientes; un hito al PT y una terraza de data histórica indeterminada (sintetizado por Yakuba, 2016).

${ }^{7}$ Este análisis de visibilidad fue dirigido exclusivamente a la 
visibilidad general de los sitios y no considera la naturaleza de los soportes que albergan el arte rupestre como tampoco las dimensiones de paneles y motivos.

${ }^{8}$ Las clases de motivos se definieron de acuerdo a la tipología elaborada por Cabello (2017): antropomorfos (representaciones de seres humanos), zoomorfos (representaciones de animales) y geométricos (figuras semejables a elementos geométricos). Al interior de las dos primeras clases se realizan distinciones según los atributos cualitativos de las figuras: antropomorfos con/sin vestimenta y tipos de animales según el orden, la familia o la especie. La última categoría, en cambio, define los motivos según el número de elementos geométricos en simples (1) o compuestos

\section{Referencias bibliográficas}

Advis, P. (1990). La doctrina de Tarapacá en el siglo XVI (perfil administrativo eclesiástico). Camanchaca, 12/13, 76-92.

Albornoz, P. \& Mc Phee, B. (2008). Ser quechua, pero no indio o las paradojas de la etnicidad: Construyendo una identidad étnica en Mamiña. (Tesis inédita de licenciatura en antropología). Universidad Academia de Humanismo Cristiano, Santiago.

Alcedo y de Herrera, A. (1976 [1786-1789]). Diccionario geográfico histórico de la Indias Occidentales o América (1786-1789) (Tomo I). Madrid: Imprenta Manuel González.

Arenas, M. (2013). Significantes rupestres coloniales del sitio Toro Muerto (Chile): Canon descriptivo y comentario preliminar. Boletín de la Sociedad de Investigación del Arte Rupestre de Bolivia, 27, 87-104.

Arenas, M. \& Martínez, J. L. (2007). Del camélido al caballo: Alteridad, apropiación y resignificación en el arte rupestre colonial andino. En Actas del VI Congreso Chileno de Antropología (Tomo II). Valdivia: Colegio de Antropólogos de Chile.

(2009). Construyendo nuevas imágenes sobre los Otros en el arte rupestre andino colonial. Revista Chilena de Antropología Visual, 13, 17-36.

Arenas, M. \& Odone, M. C. (2015). Cruz en la piedra: Apropiación selectiva, construcción y circulación de una imagen cristiana en el arte rupestre andino colonial. Estudios Atacameños, 51, 137-151. (2016). Despliegues visuales en instalaciones religiosas de los Andes del sur: Una reflexión desde el arte rupestre colonial y la etnohistoria. Boletín del Museo Chileno de Arte Precolombino, 21(1), 63-78.

Aschero, C. (2000). Figuras humanas, camélidos y espacios en la interacción circumpuneña. En Podestá, M. \& Hoyos, M. de (Eds.), Arte en las rocas: Arte rupestre, menhires y piedras de colores en Argentina (pp. 15-44). Buenos Aires: Sociedad Argentina de Antropología, Instituto Nacional de Antropología y Pensamiento Latinoamericano.

Berenguer, J. (1994). Asentamientos, caravaneros y tráfico de larga distancia en el norte de Chile: El caso de Santa Bárbara. En Albeck, M. (Ed.), De costa a selva: Intercambio y producción en los
(2 o más) y estos según si las normas de diseño que relacionan los elementos son simétricas (traslación, reflexión, rotación) o no simétricas (apendicular, intersección, inscripción).

${ }^{9}$ Término tomado del destacado antropólogo Gabriel Martínez (1989).

${ }^{10}$ En tiempos coloniales, los poblados de Mamiña, Iquiuca y Parca eran anexos parroquiales del curato de Tarapacá y contaban con capilla o iglesia. A fines del siglo XIX, el poblado de Mamiña ya era una doctrina independiente y las localidades de Parca, Iquiuca, Quipisca y Macaya estaban bajo su administración (Espinoza, 2013 [1897]; Odone, 1994; Figueroa, 2005; Hidalgo, 2009).

Andes Centro-Sur (pp. 17-50). Buenos Aires: Instituto Interdisciplinario Tilcara, Universidad de Buenos Aires.

(1995). Impacto del caravaneo prehispánico tardío en Santa Bárbara. En Actas del XIII Congreso Nacional de Arqueología Chilena. Antofagasta: Sociedad Chilena de Arqueología, Universidad de Antofagasta.

(2013). Unkus ajedrezados en el arte rupestre del sur del Tawantinsuyu: ¿La estrecha camiseta de la nueva servidumbre? En Albeck, M. E., Ruiz, M. \& Cremonte, M. B. (Eds.), Las tierras altas del área centro sur andina entre el 1000 y el 1600 d.C., (pp. 311-352). Jujuy: CREA, Universidad Nacional de Jujuy.

Berenguer, J. \& Cáceres, I. (2008). Los inkas en el Altiplano Sur de Tarapacá: El Tojo revisitado. Chungara, Revista de Antropología Chilena, 40(2), 121-143.

Berenguer, J. \& Pimentel, G. (2010). Introducción: Simposio Arqueología de los "espacios vacíos": Una aproximación intermodal a las relaciones intersocietales. En Actas del XVII Congreso Nacional de Arqueología Chilena, Tomo II. Valdivia: Kultrún.

(2017). Introducción al estudio de los espacios internodales y su aporte a la historia, naturaleza y dinámica de las ocupaciones humanas en zonas áridas. Estudios Atacameños, 56, 3-11.

Berenguer, J. \& Salazar, D. (2017). Incaguasi, "donde dormían las carretas": Arqueología de un lugar de paso en el valle del Alto Loa, desierto de Atacama. Estudios Atacameños, 56, 163-195.

Berenguer, J., Cáceres, I., Sanhueza, C. \& Hernández, P. (2005). El Qhapaqñan en el Alto Loa, norte de Chile: Un estudio micro y macromorfológico. Estudios Atacameños, 29, 7-39.

Bermúdez, O. (1963). Historia del salitre: Desde sus orígenes hasta la guerra del Pacífico. Santiago: Universidad de Chile.

Bibar, G. (1966). Crónica y relación copiosa y verdadera de los reynos de Chile. Santiago: Fondo Historiadores José Toribio Medina.

Billinghurst, G. (1886). Estudios sobre la geografía de Tarapacá. Santiago: Imprenta de El Progreso.

Boletín de la Guerra del Pacífico (1979 [1879-1881]). Santiago: Andrés Bello. 
Bollaert, W. (1860). Antiquarian, ethnological and other researches in New Granada, Equador, Peru and Chili. Londres: Trubner \& Co. Paternoster Row.

Briones, L. (2006). The geoglyphs of the north Chilean desert: An archaeological and artistic perspective. Antiquity, 80, 9-24.

Briones, L. \& Espinosa, G. (1991). Investigación y rescate de un sitio con arte rupestre: Cerro Colorado, I Región, Norte de Chile. Boletín Sociedad de Investigación del Arte Rupestre de Bolivia, 5 , 80-86.

Briones, L., Núñez, L. \& Standen, V. (2005). Geoglifos y tráfico prehispánico de caravanas de llamas en el desierto de Atacama (norte de Chile). Chungara, Revista de Antropología Chilena, 37(2), 195-223.

Cabello, G. (2017). Marcando yacimientos: Pinturas rupestres y minería en la región de Atacama, Chile (660-1300 d.C.). (Tesis inédita de doctorado). Universidad de Buenos Aires, Buenos Aires.

Cabello, G. \& Gallardo, F. (2014). Iconos claves del Formativo en Tarapacá (Chile): El arte rupestre de Tamentica y su distribución regional. Chungara, Revista de Antropología Chilena, 46(1), 11-24.

Cabello, G., Gallardo, F. \& Odone, C. (2013). Las pinturas costeras de Chomache y su contexto económico-social (región de Tarapacá, norte de Chile). Boletín del Museo Chileno de Arte Precolombino, 18(1), 49-66.

Callegari, A., Wisnieski, L., Spengler, G., Rodríguez, G. \& Aumont, S. (2009). Nuevas manifestaciones del arte rupestre del Oeste Riojano: Su relación con el paisaje y con otras expresiones del arte Aguada. En Sepúlveda, M., Briones, L. \& Chacama, J. (Eds.), Crónicas sobre la piedra, arte rupestre de las Américas (pp. 381-402). Arica: Universidad de Tarapacá.

Capetillo, M. J. \& Navarro, M. (2016). Informe de monitoreo arqueológico compartido: Comunidad Indígena Quechua de Mamiña, Iquique. Manuscrito.

Cases, B. \& Montt, I. (2013). Las túnicas rupestres pintadas de la cuenca media y alta del Loa vistas desde Quillagua (norte de Chile). Chungara, Revista de Antropología Chilena, 45(2), 249-275.

Cases, B., Rees, Ch., Pimentel, G., Labarca, R. \& Leiva, D. (2008). Sugerencias desde un contexto funerario en un "espacio vacío" del desierto de Atacama. Boletín del Museo Chileno de Arte Precolombino, 13(1), 51-70.

Cerda, P., Fernández, S. \& Estay, J. (1985). Prospección de geoglifos de la provincia de lquique, primera región Tarapacá, norte de Chile: Informe preliminar. En Aldunate, C., Berenguer, J. \& Castro, V. (Eds.), Estudios en arte rupestre (pp. 311-348). Santiago: Museo Chileno de Arte Precolombino.

Chacama, J. (2003). Hombres, pájaros y hombres-pájaros: Análisis de figuras humanas y aves sobre roca, quebrada de Aroma, sitio Ariquilda 1, extremos norte de Chile. En Actas del 51 Congreso Internacional de Americanistas. Santiago.

Chacama J. \& Briones, L. (1996). Arte rupestre en el desierto tarapaqueño, norte de Chile. Boletín Sociedad de Investigación del Arte Rupestre de Bolivia, 10, 41-51.

Chacama, J. \& Espinosa, G. (1997). La ruta de Tarapacá: Análisis de un mito y una imagen en el norte de Chile. En Actas del
XIV Congreso Nacional de Arqueología Chilena (Tomo 2). Copiapó: Museo Regional de Atacama.

CIQM (2016). Paisaje cultural y límites territoriales de la comunidad indígena quechua de Mamiña. Auditorías e Investigaciones Socioambientales y Territoriales Ñanthaqui. Manuscrito.

CIQQ (2014). Caracterización socioantropológica de la comunidad de Quipisca. Fundación Desierto de Atacama. Manuscrito.

(2016). Informe Quipisca: Línea de investigación etnohistórica. Cisternas, P. y Aguilar, J. (Autores). Manuscrito.

(2017a). Catastro arqueológico y patrimonial del territorio de Quipisca, región de Tarapacá. Fundación Desierto de Atacama. Manuscrito.

(2017b). Estudio y caracterización general de los geoglifos de Quipisca. Fundación Desierto de Atacama (Autor). Manuscrito.

Clarkson, P. (1996). Técnicas de determinación de las edades cronológicas de geoglifos. Chungara, Revista de Antropología Chilena, 28(1/2), 419-460.

(1999). Considérations historiques et contextualisation de la recherche sur les géogliphes au Chili. Anthropologie et Sociétés, 23(1), 125-150.

Clarkson, P. \& Briones, L. (2001). Geoglifos, senderos y etnoarqueología de caravanas en el desierto chileno. Boletín del Museo Chileno de Arte Precolombino, 8, 35-45.

Clarkson, P., Rivera, M. \& Dorn, R. (2001). Manifestaciones culturales en la región de Guatacondo: Los primeros fechados numéricos de geoglifos. En Berenguer, J., Cornejo, L., Gallardo, F. \& Sinclaire, C. (Eds.), Segundas jornadas de arte y arqueología (pp. 109-114). Santiago: Museo Chileno de Arte Precolombino.

Cobo, J. (1971). Yo vi nacer y morir los pueblos salitreros. Santiago: Quimantú.

CONADI (2013). Pueblos originarios de la provincia del Tamarugal: Conocimientos tradicionales de ecología de las comunidades indígenas de la provincia del Tamarugal. lquique: Corporación Nacional de Desarrollo Indígena.

Correa, I. \& García, M. (2014). Cerámica y contextos de tránsito en la ruta Calama-Quillagua, vía Chug-Chug, desierto de Atacama, norte de Chile. Chungara, Revista de Antropología Chilena, 46(1), 25-50.

Espinoza, E. (2013[1897]). Geografía descriptiva de la República de Chile. Santiago: Cámara Chilena de la Construcción, Pontificia Universidad Católica de Chile, Dirección de Bibliotecas, Archivos y Museos.

Estica, N. (2006). Capacitación en talleres de territorio y patrimonio comunitario indígena: Comunidad Indígena Quechua de Mamiña. Santiago: Programa Orígenes, Gobierno de Chile.

Figueroa, C. (2005). Entre la arquidiócesis de Arequipa y el vicariato de Tarapacá: Contradicciones del culto en la parroquia de Tarapacá (1893-1902). Boletín del Instituto Riva Agüero, 32, 191-212.

Galdames, L. (1990). Apacheta: La ofrenda de piedra. Diálogo Andino, 9, 10-25.

Gallardo, F. (1996). Acerca de la lógica en la interpretación del arte rupestre. Boletín de la Sociedad Chilena de Arqueología, 23, 31-33. (2018). Estilos de arte rupestre e interacción social en el 
desierto de Atacama (Norte de Chile). Mundo de Antes, 12(1), 13-78.

Gallardo, F. \& Vilches, F. (1995). Nota acerca de los estilos de arte rupestre en el Pukara de Turi (norte de Chile). Boletín de la Sociedad Chilena de Arqueología, 20, 26-28.

(2001). Arte rupestre en la época de dominación inka en el norte de Chile. En Aldunate, C. \& Cornejo, L. (Eds.), Tras la huella del inka en Chile (pp. 34-37). Santiago: Museo Chileno de Arte Precolombino.

Gallardo, F., Castro, V. \& Miranda, P. (1990). Jinetes sagrados en el desierto de Atacama: Un estudio de arte rupestre andino. Boletín del Museo Chileno de Arte Precolombino, 4, 27-56.

Gallardo, F., Cabello, G. \& Pimentel, G. (2018). Signals in the desert: Geogliphs as cultural system \& ideology (Northern Chile). En Troncoso, A., Armstrong F., \& Nash, G. (Eds.), Archaeologies of rock art: South american perspective (pp. 131-150). Londres: Routledge.

Gallardo, F., Cabello, G., Pimentel, G., Sepúlveda, M. \& Cornejo, L. (2012). Flujos de información visual, interacción social y pinturas rupestres en el desierto de Atacama (norte de Chile). Estudios Atacameños, 43, 35-52.

González, B. (2014). Discursos en el paisaje andino colonial: Reflexiones en torno a la distribución de sitios con arte rupestre colonial en Tarapacá. Diálogo Andino, 44, 75-87.

González, S. (1989). El arrieraje en Tarapacá en el ciclo salitrero. Camanchaca, 8, 10-35.

González, S. \& Artaza, P. (2013). El concepto de "cantón salitrero" y su funcionalidad social, territorial y administrativa: Los casos de Zapiga, Lagunas y El Toco. En González, S. (Ed.), La sociedad del salitre: Protagonistas, migraciones, cultura urbana y espacios públicos, 1870-1940 (pp. 325-363). Santiago: RIL.

Hernández, R. (1930). El salitre (resumen histórico desde su descubrimiento y explotación). Valparaíso: Fisher Hermanos.

Hidalgo, J. (2004). Proyectos coloniales inéditos de riego del desierto: Azapa (Cabildo de Arica, 1619), Pampa lluga (O'Brien, 1765) y Tarapacá (Mendizábal, 1807). En Hidalgo, J. (Ed.), Historia andina de Chile (pp. 354-379). Santiago: Editorial Universitaria. (2009). Civilización y fomento: La "Descripción de Tarapacá" de Antonio O'Brien, 1765. Chungara, Revista de Antropología Chilena, 41(1), 5-44.

JIA (2013). Línea base patrimonio cultural proyecto continuidad operacional CMCC. Manuscrito.

Larraín, H. (1975). La población indígena de Tarapacá (norte de Chile), entre 1538 y 1581. Norte Grande, 1(3-4), 269-300.

(Ed.) (2012). Historia y vida en el valle de Quipisca: Evolución cultural de una comunidad andina. Iquique: Comunidad Indígena Quechua Quipisca.

López Campeny, S. \& Martel, A. (2014). La vestimenta del poder: Comparando los registros textil y rupestre en el noroeste de Argentina (siglos XIII a XV). Relaciones de la Sociedad Argentina de Antropología, 39(1), 21-55.

Lorandi, A. M. (1966). El arte rupestre del noroeste argentino (área del norte de La Rioja y sur y centro de Catamarca). Dédalo, Revista de Arte e Arqueología, 2(4), 15-72.
Loyola, R. (2013). Anexo E: Arqueología proyecto obras de protección de cauce CMCC, Compañía Minera Cerro Colorado Ltda. Santiago: Proust Consultores.

Lynch, T. (1995-1996). Inka roads in the Atacama: Effects of latter use by mounted travallers. Diálogo Andino, 14-15, 187-203.

Martínez, G. (1989). El sistema de los Uywuiris en Isluga. En Martínez, G., Espacio y pensamiento: I. Andes meridionales (pp. 13-107). La Paz: Hisbol.

Martínez, J. L. (2009). Registros andinos al margen de la escritura: El arte rupestre colonial. Boletín del Museo Chileno de Arte Precolombino, 14(1), 9-35.

Meighan, C. W. (1980). Archaeology of Guatacondo. En Meighan, C. W. \& True, A. L. (Eds.), Prehistoric trails of Atacama:Archaeology of Northern Chile (pp. 99-126). Los Angeles: The Institute of Archaeology, University of California.

Montt, I. (2005). Vestimenta en la cultura visual tardía del desierto de Atacama. (Tesis inédita de licenciatura en arqueología). Universidad de Chile, Santiago.

Moragas, C. (1996). Manifestaciones rupestres en el tramo bajo de la quebrada de Tambillos. Chungara, Revista de Antropología Chilena, 28(1-2), 241-252.

Moragas, C., Briones, L., Carrasco, C., Ajata, R., Rocha, R. \& Contreras, L. (2006). Informe final componente de arqueología proyecto actualización faenas Cerro Colorado. Santiago: Knight Piésold Consulting.

Mostny, G. (1970). Arqueología de la Quebrada de Guatacondo. Órbita, Revista de Ciencia y Tecnología, 6, 6-20.

Mostny, G. \& Niemeyer, H. (1963). Informe sobre investigaciones arqueológicas en la quebrada de Guatacondo. Noticiario Mensual Museo Nacional de Historia Natural, 86, 2-6.

Mostny, G. \& Niemeyer, H. (1983) Arte rupestre chileno. Santiago: Departamento de Extensión Cultural, Ministerio de Educación.

Muñoz, I. \& Briones, L. (1996). Poblados, rutas y arte rupestre precolombinos de Arica: Descripción y análisis de sistemas de organización. Chungara, Revista de Antropología Chilena, 28(1/2), 47-84.

Nielsen, A. (1997). El tráfico caravanero visto desde La Jara. Estudios Atacameños, 14, 339-371. (1997-1998). Tráfico de caravanas en el sur de Bolivia: Observaciones etnográficas e implicancias arqueológicas. Relaciones de la Sociedad Argentina de Antropología, 22-23, 139-178.

(2006). Estudios internodales e interacción interregional en los Andes circumpuneños: Teoría, método y ejemplos de aplicación. En Lechtman, H. (Ed.), Esferas de interacción prehistóricas y fronteras nacionales modernas en los Andes sur centrales (pp. 29-62). Lima: Instituto de Estudios Peruanos, Institute of Andean Research.

(2007). Armas significantes: Tramas culturales, guerra y cambio social en el sur andino prehispánico. Boletín del Museo Chileno de Arte Precolombino, 12(1), 9-41.

Niemeyer, H. (1961). Excursiones a la Sierra de Tarapacá: Arqueología, toponimia y botánica. Universitaria, 46, 97-122.

Núñez, L. (1965a). Prospección arqueológica en el norte de Chile. 
Estudios Arqueológicos, 1, 9-35.

(1965b). Estudio comparativo sobre petroglifos del norte de Chile. Annals of the Náprstek Museum, 4, 37-153.

(1976). Geoglifos y tráfico de caravanas en el desierto chileno. En Niemeyer, H. (Ed.), Homenaje al Dr. Gustavo Le Paige (pp. 147-201). Antofagasta: Universidad del Norte.

(1985). Petroglifos y tráfico de caravanas en el desierto chileno. En Aldunate, C., Berenguer, J. \& Castro, V. (Eds.), Estudios en arte rupestre (pp. 243-264). Santiago: Museo Chileno de Arte Precolombino.

Núñez, L. \& Briones, L. (1967-1968). Petroglifos del sitio Tarapacá-47 (provincia de Tarapacá). Estudios Arqueológicos, 3/4, 43-75.

Odone, C. (1994). La territorialidad indígena y española en Tarapacá colonial (siglos XVI-XVIII): Una proposición. (Tesis inédita de licenciatura en historia). Instituto de Historia, Pontificia Universidad Católica de Chile, Santiago.

(2018). Lecturas de caminos, huellas y senderos: Historias y memorias en las quebradas de Quipisca, Mamiña, Iquiuca y Parca. Proyecto Medidas de Compensación General de Difusión y Educación Patrimonial, Proyecto Continuidad Operacional Cerro Colorado. Manuscrito.

Olmos, S., Capetillo, M., Riffo, C. \& Pinto, M. (2018). Viajes en el desierto: Paisaje, memoria y experiencia en la hoya de Tambillo. Iquique: Fondo Nacional de Desarrollo Cultural y las Artes.

Pimentel, G. (2009). Las huacas del tráfico: Arquitectura ceremonial en rutas prehispánicas del desierto de Atacama. Boletín del Museo Chileno de Arte Precolombino, 14(2), 9-38.

(2012). Redes viales prehispánicas en el desierto de Atacama: Viajeros, movilidad e intercambio. (Tesis inédita de doctorado en antropología). Universidad de Tarapacá, Universidad Católica del Norte, Antofagasta.

Pimentel, G. \& Montt, I. (2008). Tarapacá en Atacama: Arte rupestre y relaciones intersocietales entre el 900 y 1450 d.C. Boletín del Museo Chileno de Arte Precolombino, 13, 35-50.

Pimentel, G., Rees, C., De Souza, P., \& Arancibia, L. (2011). Viajeros costeros y caravaneros: Dos estrategias de movilidad en el período formativo del desierto de Atacama, Chile. En Núñez, L. \& Nielsen, A. (Eds.), En ruta: Arqueología, historia y etnografía del tráfico sur andino (pp. 43-81). Córdoba: Brujas.

Pimentel, G., Rees, C., De Souza, P. \& Ayala, P. (2010). Estrategias de movilidad del período formativo en la depresión intermedia, desierto de Atacama. En Actas del XVII Congreso Nacional de Arqueología Chilena (Tomo II). Valdivia: Kultrún.

Podestá, M. M., Rolandi, D. S., Re, A., Falchi, M. P. \& Damiani, O. (2006). Arrieros y marcas de ganado: Expresiones del arte rupestre de momentos históricos en el desierto de Ischigualasto. En Fiore, D. \& Podestá, M. (Eds.), Tramas en la piedra, producción y uso del arte rupestre (pp. 205-220). Buenos Aires: WAC, Sociedad Argentina de Arqueología, Asociación Amigos del Instituto Nacional de Antropología.

Risopatrón, L., (1924). Diccionario geográfico de Chile. Santiago:
Imprenta Universitaria.

Rivera, M. \& Clarkson, P. (1997). Geoghyps and caravan trails of the Tarapacá Desert. Manuscrito.

Santoro, C., Capriles, J., Gayó, E., Porras, M. E. de, Maldonado, A., Standen, V., Latorre, C., Castro, V., Angelo, D., McRostie, V., Uribe, M., Valenzuela, D., Ugalde, P. \& Marquet, P. (2017). Continuities and discontinuities in the socio-environmental systems of the Atacama Desert during the last 13000 years. Journal of Antropological Archaeology, 46, 28-39.

Sepúlveda, M. (2004). Esquemas visuales y emplazamiento de las representaciones rupestres de camélidos del Loa superior en tiempos incaicos: ¿Una nueva estrategia de incorporación de este territorio al Tawantinsuyu? Chungara, Revista de Antropología Chilena, 36(2), 439-451.

Sepúlveda, M., Romero, A. \& Briones, L. (2005). Tráfico de caravanas, arte rupestre y ritualidad en la quebrada de Suca (extremo norte de Chile). Chungara, Revista de Antropología Chilena, 37, 225-243.

Sinclaire, C. (1994). Los sitios de "muros y cajas" del río Loa y su relación con el tráfico de caravanas. En Albeck, M. (Ed.), Taller de costa a selva (pp. 51-76). Buenos Aires: Instituto Interdisciplinario Tilcara, Universidad de Buenos Aires.

Solano, F. (1867). Diccionario geográfico de la República de Chile. Santiago.

Troncoso, A. (2011). Personajes fuera de lugar: Antropomorfos tardíos en el arte rupestre del norte semiárido de Chile. Intersecciones en Antropología, 12, 221-230.

Urbina, S., \& Adán, L. (2006). Construcciones de uso público y distribución en las quebradas tarapaqueñas durante el periodo intermedio tardío (900-1450 años d.C.). Boletín de la Sociedad Chilena de Arqueología, 39, 19-34.

Urbina, S., Adán, L. \& Pellegrino, C. (2012) Arquitecturas formativas de las quebradas de Guatacondo y Tarapacá a través del proceso aldeano (ca. 900 a.C.-1000 d.C.). Boletín del Museo Chileno de Arte Precolombino, 17(1), 31-60.

Uribe, M. (2006). Acerca de complejidad, desigualdad social y complejo cultural Pica-Tarapacá en los Andes centro sur (1000-1450 d.C.). Estudios Atacameños, 31, 91-114.

Uribe, M. \& Cabello, G. (2005). Cerámica en el camino: Implicancias tipológicas y conductuales para la comprensión de la vialidad y la expansión del Tawantinsuyo en el río Loa (Norte Grande de Chile). Revista Española de Antropología Americana, 35, 75-98.

Uribe, M. \& Sánchez, R. (2016). Los incas en Chile: Aportes de la arqueología chilena a la historia del Tawantinsuyu (ca. 1400 a 1536 d.C.). En Falabella, F., Uribe, M., Sanhueza, L., Aldunate, C. \& Hidalgo, J. (Eds.), Prehistoria en Chile: Desde sus primeros habitantes hasta los incas (pp. 529-572). Santiago: Editorial Universitaria.

Uribe, M., Sanhueza, L. \& Bahamondes, F. (2007). La cerámica prehispánica tardía de Tarapacá, sus valles interiores y costa desértica, norte de Chile (ca. 900-1450 d.C.): Una propuesta tipológica y cronológica. Chungara, Revista de Antropología Chilena, 39(2), 143-170. 
Urrutia, F. (2011). Participación social en la quebrada de Camiña: Entre los avatares de la tradición y la dinámica municipal. (Tesis inédita de licenciatura en antropología social). Universidad de Chile, Santiago.

Valenzuela, D., Briones, L. \& Santoro, C. (2006). Arte rupestre en el paisaje: Contextos de uso del arte rupestre en el valle de Lluta, norte de Chile, períodos intermedio tardío y tardío. En Fiore, D. \& Podestá, M. (Eds.), Tramas en la piedra, producción y uso del arte rupestre (pp. 205-220). Buenos Aires: WAC, Sociedad Argentina de Arqueología, Asociación Amigos del Instituto Nacional de Antropología.

Valenzuela, D., Santoro, C. \& Briones, L. (2011). Arte rupestre, tráfico e interacción social: Cuatro modalidades en el ámbito exorreico de los valles occidentales, norte de Chile (períodos intermedio tardío y tardío, ca. 1000-1535 d.C.). En Núñez, L. \& Nielsen, A. (Eds.), En ruta: Arqueología, historia y etnografía del tráfico sur andino (pp. 199-245). Córdoba: Brujas.

Van Kessel, J. (1980). Holocausto al progreso: Los aymarás de Tarapacá. Amsterdam: Centro de Estudios para el Desarrollo Laboral y Agrario.

Vilches, F. (1999). Inka rock art?: Minor arts, major meanings. (Tesis inédita de maestría en arte). University of Maryland, Washington.

Vilches, F. \& Cabello, G. (2011). Variaciones sobre un mismo tema: El arte rupestre asociado al complejo Pica-Tarapacá, norte de Chile. Chungara, Revista de Antropología Chilena, 43(1), 37-52.
Villalobos, S. (1979). La economía de un desierto: Tarapacá durante la colonia. Santiago: Nueva Universidad.

Weiss, A. (2001). Topographic position and landforms analysis. ESRI User Conference, San Diego.

Westfall, K. \& Vargas, C. (2015). Trazos tarapaqueños: Aerofotogrametría de los geoglifos de Quipisca. Santiago: TaguaTagua Consultores.

Yakuba, S. (2016). Registro integral sitios arqueológicos: Informe huellas y senderos. Medida cumplimiento RCAn 0069/2015. Estudio de impacto ambiental proyecto continuidad operacional Cerro Colorado. Spondylus Arqueólogos Consultores, Golder Associates y BHP Billiton, Santiago.

Zori, C. \& Brant, E. (2017). Lanzando una amplia red: Un análisis de redes sociales en los caminos incas en los valles costeros del norte de Chile. En Chacaltana, S., Arkush, E. \& Marcone, G. (Eds.), Nuevas tendencias en el estudio de los caminos (pp. 72-99). Lima: Ministerio de Cultura.

Zori, C., Brant, E. \& Uribe, M. (2017). Empires as social networks: Roads, connectedness, and the Inka incorporation of northern Chile. Nawpa Pacha, Journal of Andean Archaeology, 37(1), 1-23.

Zori, C. \& Urbina, S. (2014). Architecture and empire at late prehispanic Tarapacá Viejo, northern Chile. Chungara, Revista de Antropología Chilena, 46(2), 211-232. 